\title{
Tipula (Vestiplex) from Yunnan and Tibet, China: one new species and redescriptions of five known species (Diptera: Tipulidae)
}

\author{
Qiu-Lei MEN ${ }^{1)}$, Pavel STARKEVICH ${ }^{2 *}$, Li-Fan $\mathrm{HE}^{3)}$, Jian-Xiong SHI ${ }^{3)}$, Mei-Ying SHI ${ }^{3)}$, Zhong-Xin ZHANG ${ }^{1)}$, \\ Jia-Hui $\mathrm{HU}^{1)}$, An $\mathrm{CHEN}^{1)}$ \& Yi-Xue $\mathrm{ZHANG}^{1)}$

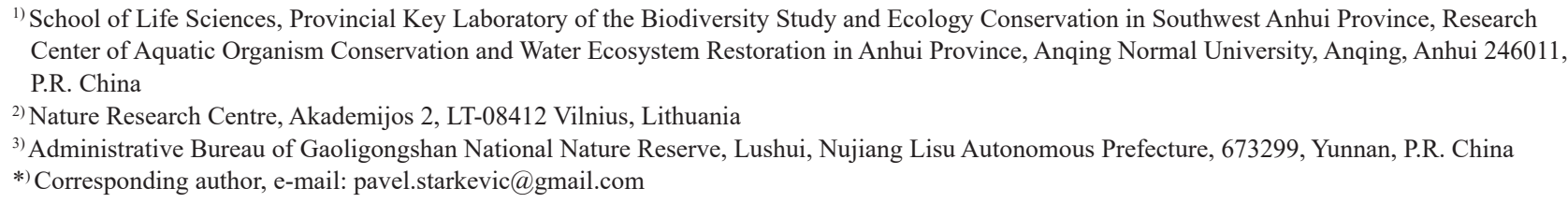

Accepted:

$10^{\text {th }}$ August 2021

Published online: $22^{\text {nd }}$ September 2021

\begin{abstract}
A new crane fly species Tipula (Vestiplex) lushuiensis Men \& Starkevich, sp. nov., is described and illustrated based on materials collected in Yunnan and Tibet, China. Tipula (V.) alyxis Alexander, 1963, T. (V.) guibifida Yang \& Yang, 1992, T. (V.) himalayensis Brunetti, 1911, T. (V.) quasimarmoratipennis Brunetti, 1912 and T. (V.) reposita Walker, 1848 are redescribed and illustrated based on additional morphological characters. Tipula $(V$. quasimarmoratipennis and $T$. $(V$.$) reposita are listed as new records for the Chinese fauna.$ Male of $T$. ( $V$. ) quasimarmoratipennis and females of $T$. (V.) alyxis, T. (V.) guibifida and $T$. ( $V$.) himalayensis are illustrated for the first time.
\end{abstract}

Key words. Diptera, Tipuloidea, Tipulidae, distribution, hypopygium, new synonym, female terminalia, taxonomy, China

Zoobank: http://zoobank.org/urn:lsid:zoobank.org:pub:C1A6C884-743E-471A-9632-4A769F6BC0EB

(C) 2021 The Authors. This work is licensed under the Creative Commons Attribution-NonCommercial-NoDerivs 3.0 Licence.

\section{Introduction}

The subgenus Vestiplex Bezzi, 1924 of Tipula Linnaeus, 1758, was established by BEZzI (1924) with the type species Tipula cisalpina Riedel, 1913, from the West Palaearctic Region, by original designation. Many species of the subgenus Vestiplex were originally placed in the subgenus Oreomyza Pokorny, 1887, which was subsequently treated as a synonym of the subgenus Pterelachisus Rondani, 1842 (AlEXANDER 1965). Vestiplex is a relatively large subgenus of Tipula with 178 species and subspecies worldwide, which are distributed in the Holarctic and Oriental Regions (OosTERBROEK 2021). There are 75 species and one subspecies of Vestiplex in China, mainly restricted to the southern part of the country (OOSTERBROEK 2021). Its subgeneric characters were summarized by ALEXANDER (1935a), MEN et al. (2017) and STARKEVICH et al. (2019).
Northwest Yunnan and southeast Tibet, as connecting areas, have a very complex topography (huge mountains, snow mountain, large unpopulated areas or high mountain meadows) and very different climates (tropics, subtropics, temperate or frigid zone), which made these areas rich in species diversity. However, investigation of crane fly species in these areas has been poorly carried out.

While sorting and identifying crane flies collected from Yunnan and Tibet, one new species and five known species of Vestiplex were found. The present paper provides the description and the illustration of the external morphology of the new species. The original descriptions of the known species are expanded using descriptions of new morphological characters and detailed illustrations. New distribution records are provided. 


\section{Material and methods}

Adult crane flies were collected with insect net and ultraviolet lamp in Tibet and Yunnan Province during fieldworks in 2019.

Photographs of the body parts were taken with an Olympus SZ61 stereomicroscope (Olympus, Japan). The hypopygium was removed and macerated in $10 \% \mathrm{NaOH}$ for one hour in $50^{\circ} \mathrm{C}$ metal bath, observed in glycerin and illustrated under the same stereomicroscope. Cleared genitalia are preserved in a microvial filled with glycerol and pinned together with the corresponding type specimen. The body length was measured from the vertex of head to the tip of hypopygium. All measurements were made in millimeters $(\mathrm{mm})$ with the aid of a digital caliper.

Descriptive terminology generally follows that of $\mathrm{CuM}=$ MING \& WoOD (2017) with some additions for particular features for some Vestiplex. The term appendage of sternite nine (A9S) is adopted from ManNHEIMs (1963). The terms ventral lobe and dorsal lobe of appendage of sternite nine are adopted from Gelhaus (2005). The terminology of wing venation is adopted from DE JONG (2017).

The pinned specimens including the type material are deposited at the School of Life Sciences, Anqing Normal University, Anhui, China. Abbreviations for institutional collections used herein:

AQNU Anqing Normal University, Anqing, China;

BMNH Natural History Museum, London, United Kingdom;
NRC Nature Research Centre, Vilnius, Lithuania;

USNM Smithsonian, National Museum of Natural History, Washington, D.C., USA.

The following specimens were studied for comparative purposes:

Tipula (V) sternotuberculata Alexander, 1935: HolOTYPe: CHINA: TaIwan: ㄱ, Taiwan, Arisan, 7640 ft., 24.v.1934, coll. L. Gressit (USNM); PARATYPE: 1 §̋, 6200 ft., 26.v.1934, coll. L. Gressit (USNM). Tipula (V.) leigongshanensis Men \& Young, 2017: НоLOTYPE: CHINA: Guizhou: $\delta^{\curvearrowright}$, Leigongshan Mountain, $26^{\circ} 21^{\prime} \mathrm{N}, 108^{\circ} 13^{\prime} \mathrm{E}, 2 . v i .2015$, coll. G. Xue.

\section{Taxonomy}

\section{Tipula (Vestiplex) lushuiensis Men \& Starkevich sp. nov. (Figs 1-14)}

Type locality. China, Yunnan, Lushui County, Pianma, $26^{\circ} 00^{\prime} \mathrm{N} 98^{\circ} 37^{\prime} \mathrm{E}$. Type material. Holotype: $\widehat{\jmath}$, CHINA: Yunnan: Pianma, Lushui County, 19.vi.2019, coll. Q. Men \& L. Lv (AQNU). PARATYPE: 1 \%, the same data as holotype (AQNU).

Diagnosis. General body coloration yellow. Flagellum bicolored with terminal segments brown. Prescutum and presutural scutum yellow with three brown stripes. Wing light brown with some light areas. Basal five abdominal segments yellow, trivittate, rest of segments brown with hypopygium black. Dorsal portion of tergite nine divided into two parts at midline, ventral portion with strongly

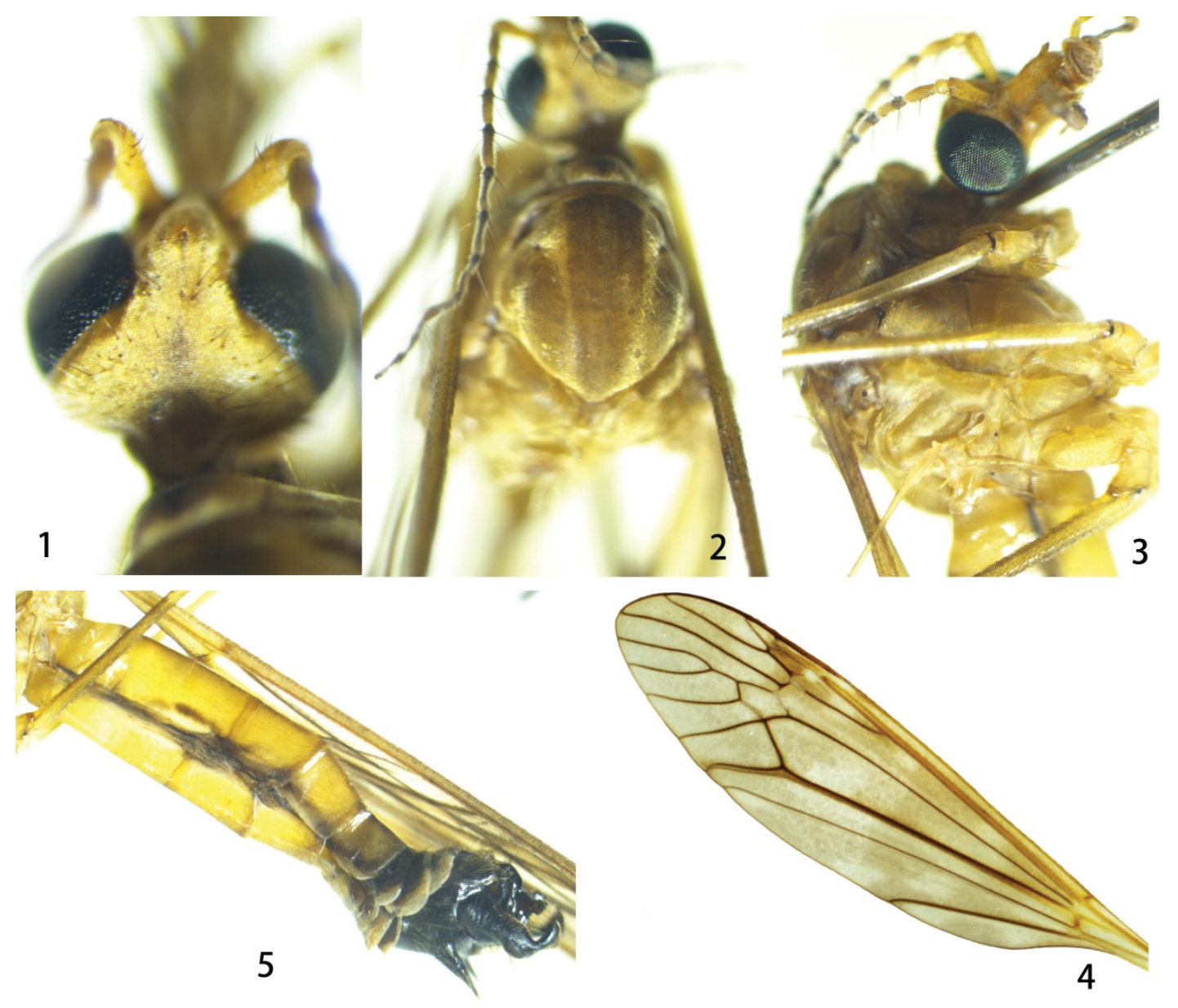

Figs 1-5. Tipula (Vestiplex) lushuiensis Men \& Starkevich sp. nov., holotype, male. 1 - head, dorsal view; 2 - thorax, dorsal view; 3 - thorax, lateral view; 4 - wing; 5 - abdomen and hypopygium, lateral view. 
blackened structure terminating in two flattened, apically rounded plates. Gonocoxite massive and elongated, curved with apex funnel-shaped. Sternite nine basally with pair of nail-shaped processes directed caudad.

Description. Male (Figs 1-5). Body length 12.3-12.7 mm (excluding antenna, $\mathrm{n}=2)$, wing length $17.8-18.0 \mathrm{~mm}(\mathrm{n}$
$=2)$, length of antenna 4.6-4.8 $\mathrm{mm}(\mathrm{n}=2)$. General body coloration yellow.

Head. Generally yellow, vertex and occiput with brown linear mark, broad at base, gradually narrowed to apex (Fig. 1). Rostrum yellow, nasus yellow, very short and stout, densely covered with black setae. Antenna 13-seg-
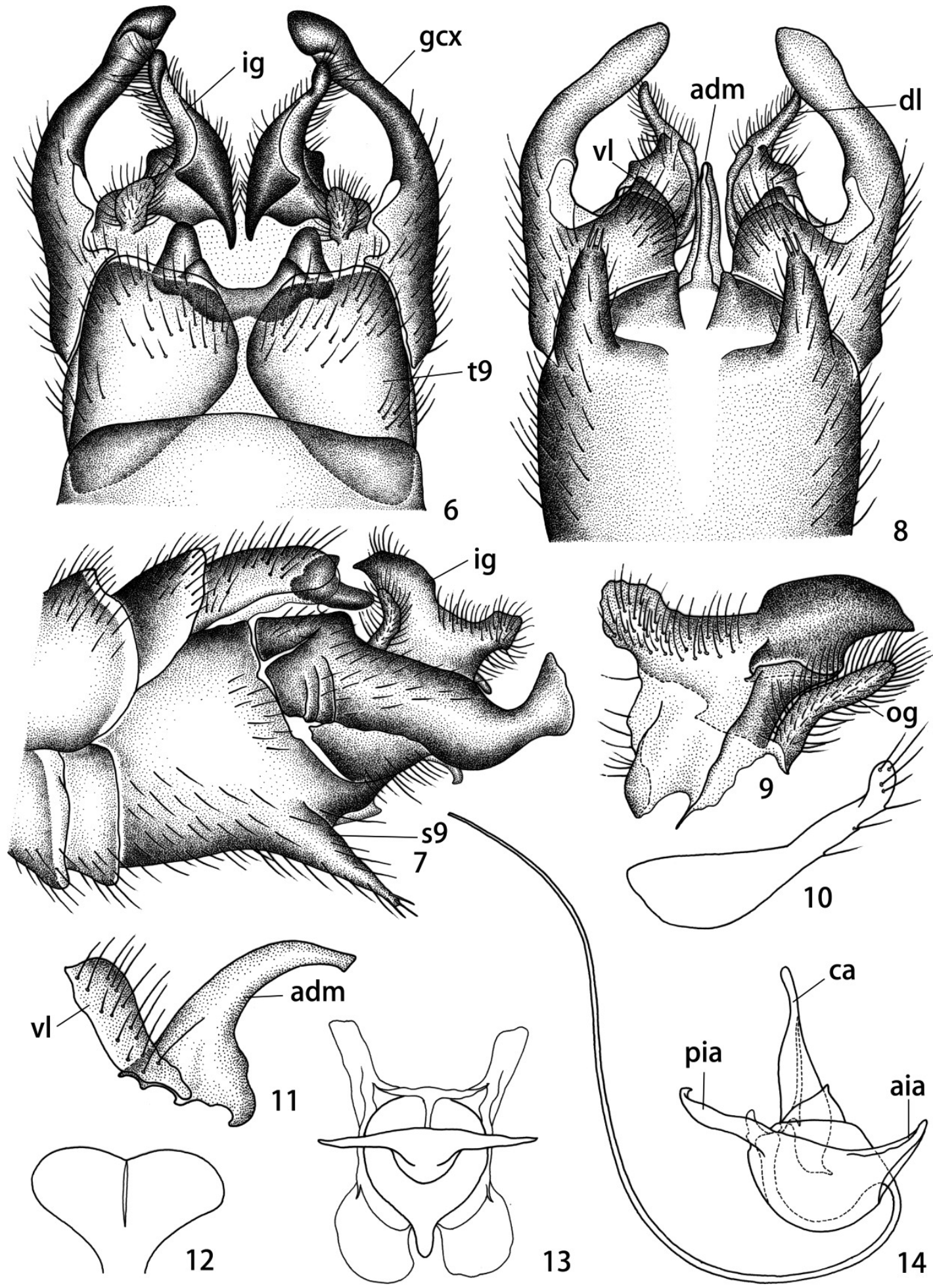

8

13

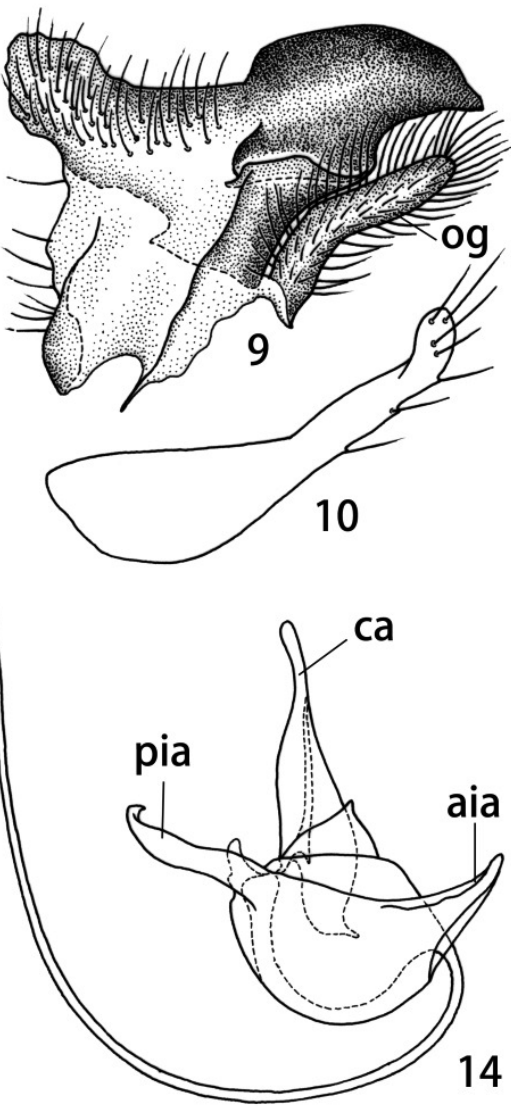

Figs 6-14. Tipula (Vestiplex) lushuiensis sp. nov., holotype, male. 6 - hypopygium, dorsal view; 7 - hypopygium, lateral view; 8 - hypopygium, ventral view; 9 - right inner and outer gonostyli, lateral view; 10 - dorsal lobe of A9S; 11 - adminiculum and ventral lobe of A9S, lateral view; 12 - compressor apodeme, dorsal view; 13 - semen pump, dorsal view; 14 - semen pump, lateral view. Abbreviations: adm - adminiculum; aia - anterior immovable apodeme; ca - compressor apodeme; dl - dorsal lobe of A9S; gcx - gonocoxite; ig - inner gonostylus; og - outer gonostylus; pia - posterior immovable apodeme; $\mathrm{s}$ - sternite; $\mathrm{t}$ - tergite; $\mathrm{vl}$ - ventral lobe of A9S. 
mented, if bent backward almost reaching root of wing (Figs 2, 3). Scape and pedicel yellow, first flagellomere yellowish, second to fifth bicolored with basal enlargement dark brown, rest of flagellomeres wholly brown. Apical flagellomere very small, reduced, distinctly shorter than preceding flagellomere. Each flagellomere except first slightly enlarged at base, with longest verticils subequal in length to their corresponding flagellomeres. Whole flagellum densely covered with short and light setae. Palpus entirely yellow, last segment almost as long as basal three segments together.

Thorax. Pronotum yellow with dark area medially. Prescutum and presutural scutum yellow with four brown stripes. Intermediate pair fused into broad brown stripe, narrowed at base and gradually expanded to rounded anterior margin. Lateral stripes brown, marginally suffused with brown on outer side. Interspace between median and lateral stripes yellowish with light and short setae (Fig. 2). Postsutural scutum yellow, each lobe with two brown triangular markings. Scutellum and postnotum yellow, with dark, narrow median vitta. Pleuron entirely yellow (Fig. 3). Legs with coxae and trochanters yellow, femora yellow with tips brown, tibiae and tarsi entirely brown. Halter with yellow stem and brown knob. Wing light brown, cell sc slightly darker than ground color, stigma dark brown, variegated by light areas, including apical area of cell c, median area of $1^{\text {st }}$ cell of cell $r_{1}$ and base of stigma, light band across apical area of cell $\mathrm{r}_{1}$, base of cells $\mathrm{r}_{3}, \mathrm{r}_{4}$ and $\mathrm{r}_{5}$, and median area of discal cell; other light areas including base and apical areas of bm, median and apical areas of cells cua and cup (Fig. 4). Venation: $\mathrm{R}_{1}$ atrophied apically, $\mathrm{R}_{2+3+4}$ slightly shorter than $\mathrm{R}_{3}, \mathrm{R}_{4}$ distinctly longer than $\mathrm{Rs}$, $\mathrm{R}_{5}$ curved in apical two fifths, $\mathrm{r}-\mathrm{m}$ slightly shorter than base of $\mathrm{R}_{5}$, discal cell narrow, two times longer than petiole of cell $\mathrm{m}_{1}$, cell $\mathrm{m}_{1}$ more than three times longer than its petiole (Fig. 4).

Abdomen. Basal five abdominal segments yellow with segment five darkened with brown lateral and intermittent median stripes. Segments six to eight dark brown, corresponding tergites with posterior and lateral margins broadly pale-yellow, hypopygium entirely black (Fig. 5).

Hypopygium. Male hypopygium with tergite nine and sternite nine separated totally (Figs 6, 7). Dorsal portion of tergite nine totally divided into two parts at midline by membranous area, each part of dorsal portion terminating into truncated posterior margin, forming V-shaped notch between them. Ventral portion of tergite nine with strongly blackened structure terminating into two flattened, apically rounded plates (Fig. 6). Gonocoxite massive and elongated, totally separated from sternite nine, broad basally, apically curved with apex funnel-shaped (Fig. 7). Outer gonostylus small and narrow (Figs 6-9). Inner gonostylus terminating into black and acute beak, upper margin of beak arched, dorsal crest protruding into obtuse lobe, with many long setae along upper margin (Figs 6-9). Sternite nine basally with pair of nail-shaped processes directed caudad and covered with setae (Fig. 8). Appendage of sternite nine with dorsal lobe broad basally, gradually narrowed to rounded apex (Figs 8,10), ventral lobe broad, densely covered with long setae (Fig. 11). Adminiculum gradually narrowed to truncated tip, curved, directed ventrad in lateral view, median sclerite narrow (Figs 8, 11). Semen pump with compressor apodeme fan-shaped, slightly concave medially, distinctly longer than posterior immovable apodeme (Fig. 12). Posterior immovable apodeme with paired arms broad and truncated at apex in dorsal view; curved dorsally in lateral view (Figs 13, 14). Anterior immovable apodeme broad at base, narrow to apex in lateral view, round at outer margin in dorsal view (Fig. 13). Aedeagus thick basally, 3.5 times longer than semen pump (Fig. 14).

Female. Unknown.

Discussion. Tipula $(V$ ) lushuiensis sp. nov. is close to T. (V.) leigongshanensis Men \& Young, 2017, T. (V.) sternotuberculata Alexander, 1935 and T. (V.) bispathifera Savchenko, 1960 (AleXANDer 1935b: 534, Pl. 2, figs 32, 33; Savchenko 1960: 889, Pl. 2, figs 1-2; Men et al. 2017: 70, figs 14-25) based on the shape of gonocoxite, tergite and sternite nine and inner gonostylus. All four species are distinguished from other T. (Vestiplex) by their sternite nine which is provided with a pair of nail-shaped processes at base.

Tipula (V.) lushuiensis sp. nov. is closest to T. (V.) leigongshanensis Men \& Young, 2017 in the shape of ventral plates of tergite nine and absence of long setae on posterior margin. Tipula (V.) bispathifera and T. (V.) sternotuberculata have tergite nine provided with a pair of tufts of long setae on either side of midline.

Tipula (V.) lushuiensis sp. nov. can be easily separated by obtuse lobe on dorsal crest of inner gonostylus which is horn-shaped in $T$. ( $V$.) leigongshanensis, $T$. (V.) bispathifera and $T$. (V.) sternotuberculata.

Tipula (V.) bispathifera was published by SAVCHENKO (1960) with the description based on a single male collected in Yunnan Province in 1957. The species was published without its subgeneric position, although Savchenko noticed it is close to the subgenus Vestiplex (SAVCHENKo 1960). Etymology. The specific name refers to the type locality of the new species, Lushui, Yunnan; adjective.

Distribution. China (Yunnan).

\section{Tipula (Vestiplex) alyxis Alexander, 1963} (Figs 15-31)

Tipula (Vestiplex) alyxis Alexander, 1963b: 322 (original description). Tipula (Vestiplex) alyxis: Oosterbroek \& Theowald (1992: 153); PILIPENKo et al. (2019: 14).

Type locality. China, Tibet, Zayu, Nyingchi, Rongtö Valley, $28^{\circ} 54^{\prime} 23.1^{\prime \prime} \mathrm{N}$ $96^{\circ} 39^{\prime} 27.9^{\prime \prime} \mathrm{E}$.

Type material examined. Tipula (Vestiplex) alyxis Alexander: HoLoTYPE: Ő, CHINA: TibeT: Rongtö Valley, 6,500 ft., 21.v.1933, coll. F. Kingdon-Ward \& R. J. H. Kaulback (BMNH; No. 246054). PARATYPES: CHINA: Tibet: 1 q, Rongtö Valley, 6,500 ft., 22.v.1933, coll. F. Kingdon-Ward \& R. J. H. Kaulback (BMNH; No. 246059); 1 , Rongtö Valley, 6,500 ft.,23.v.1933, coll. F. Kingdon-Ward \& R. J. H. Kaulback B. M. (BMNH; No. 246058); 1 ふૈ, Rongtö Valley, 23.v.1933, coll. F. Kingdon-Ward \& R. J. H. Kaulback (antenna, leg, wing and genitalia on slide) (USNM); 1 ㅇ, Rongtö Valley, 23.v.1933, coll. F. Kingdon-Ward \& R. J. H. Kaulback (antenna, legs and wing on slide) (USNM); 1 , Rongtö Valley, Zayul Rima Chu, 6,000 ft., 20.iv.1933, coll. F. Kingdon-Ward \& R. J. H. Kaulback (BMNH; No. 246057); 1 \&, Zayul Ata Kang, 8,000 ft., 17.vi.1933, coll. F. Kingdon-Ward \& R. J. H. Kaulback (BMNH; No. 24605); 1 §ै, Zayul Ata Kang, 10,000 ft., 16.vii.1933, coll. 
F. Kingdon-Ward \& R. J. H. Kaulback (antenna, leg, wing and genitalia on slide) (USNM).

Additional material examined. CHINA: TIBET: $1 \curvearrowright 1$, Shibagongli, Motuo County, 31.v.2019, coll. Q. Men (AQNU); 33 $\widehat{\jmath}$, Shangchayu, Chayu County, Linzhi, 8.vi.2019, coll. Q. Men (AQNU). YunNan: 1 ô, Pianma, Lushui County, 19.vi.2019, coll. Q. Men (AQNU).

Redescription. Male (Figs 15-18). Body length 10.3-13.5 mm (excluding antenna, $\mathrm{n}=35$ ), wing length $14.8-18.8$ $\mathrm{mm}(\mathrm{n}=35)$, length of antenna 5.3-5.8 mm $(\mathrm{n}=35)$. General body coloration yellowish.

Head. Generally yellow, vertex and occiput with dark brown linear mark (Fig. 15). Rostrum yellowish-brown, nasus yellow, very short and stout, densely covered with black setae. Antenna 13-segmented, if bent backward almost reaching base of $2^{\text {nd }}$ abdominal segment. Scape and pedicel yellow, first flagellomere yellowish-brown, rest of flagellomeres weakly bicolored, blackened at base. Apical flagellomere very small, reduced, distinctly shorter than preceding flagellomere. Each flagellomere except for first slightly enlarged at base, with longest verticils subequal in length to corresponding flagellomeres. Whole flagellum densely covered with short and light setae. Palpus with basal three segments light brown, last segment dark brown.

Thorax. Pronotum yellow. Prescutum and presutural scutum yellow with four greyish-brown stripes, median stripes narrowed at base and gradually expanded to rounded apex, merging at apex, rounded apically, marginally suffused with brown on outer side (Fig. 16). Interspace between median and lateral stripes grayish-yellow with light and short setae. Postsutural scutum yellow, each lobe with two brown triangular markings connecting to each other. Scutellum yellow, with dark median vitta at apical half. Postnotum yellow. Pleuron entirely yellow (Fig. 17). Legs with coxae, trochanters and basal one fifth of femora yellow, rest of femora brown with tip black, tibiae and tarsi entirely brown. Halter with stem yellow, knob brown. Wing light brown, cell sc slightly darker than ground color, variegated by light areas, including apical area of cell c, median area of $1^{\text {st }}$ cell of cell $r_{1}$, base of stigma, light band across apical area of stigma, base of cells $r_{3}, r_{4}$ and $r_{5}$; other light areas including base and apical areas of bm, median areas of cells cua and cup, outer end of cell $\mathrm{r}_{5}$; stigma dark brown (Fig. 18). Venation: $\mathrm{R}_{1}$ atrophied in basal half, $\mathrm{R}_{2+3+4}$ longer than $R_{3}, R_{4}$ subequal in length to $R s, R_{5}$ curved in apical half, $r-m$ distinctly shorter than base of $R_{5}$, discal cell narrow, longer than petiole of cell $\mathrm{m}_{1}$, cell $\mathrm{m}_{1}$ more than two times longer than its petiole (Fig. 18).

Abdomen. Basal four abdominal segments yellow with tergites narrowly trivittate, rest of abdominal segments including hypopygium black (Fig. 19).

Hypopygium. Male hypopygium with tergite nine and sternite nine separated totally (Figs 20, 21). Tergite nine approximately rectangular in outline, with pale furrow mid-dorsally, anterior margin concave medially, posterior margin concave, ventral portion inconspicuous, terminating into two small darkened lobes (Fig. 20). Gonocoxite broad basally, gradually narrowed and produced into curved rod, terminating into black point; in dorsal view, gonocoxite broad basally and gradually narrowed to apex, apically curved inward; surface densely covered with long setae, those of outer surface longer (Fig. 21). Sternite nine broad,

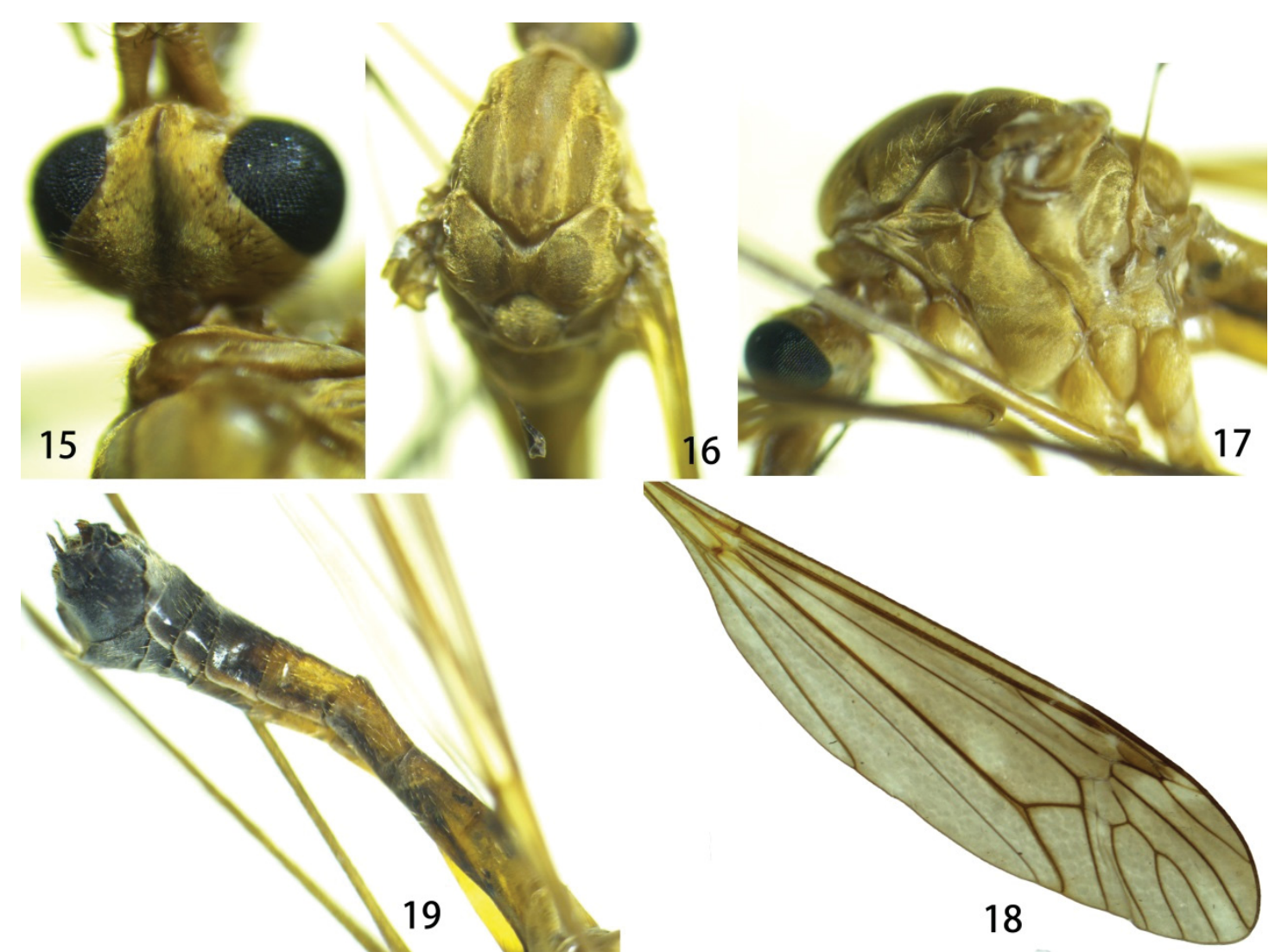

Figs 15-19. Tipula (Vestiplex) alyxis Alexander, 1963, male. 15 - head, dorsal view; 16 - thorax, dorsal view; 17 - thorax, lateral view; 18 - wing; 19 - abdomen and hypopygium, lateral view. 
densely covered with setae on lateral surface, appendage of sternite nine with ventral lobe nearly triangular, with many long setae (Fig. 22). Outer gonostylus narrowed, flattened black blade, apically curved and narrowed to obtuse apex (Fig. 23). Inner gonostylus terminating into slender black beak, lower beak black, broadened, outer crest elevated, pointed into angular tip (Fig. 24). Adminiculum laterally with two black lobes, broad basally and then narrowed to apex, with median spine gradually narrowed to sharp tip (Fig. 25). Semen pump with compressor apodeme V-shaped, each arm expanded apically (Fig. 26). Posterior immovable apodeme consisting of pair of arms, produced into angular apex in dorsal view, relatively straight in lateral view (Figs 27, 28). Anterior immovable apodeme broad and flattened (Figs 27, 28). Aedeagus thick at base, gradually narrowed to apex, more than five times longer than semen pump (Fig. 28).

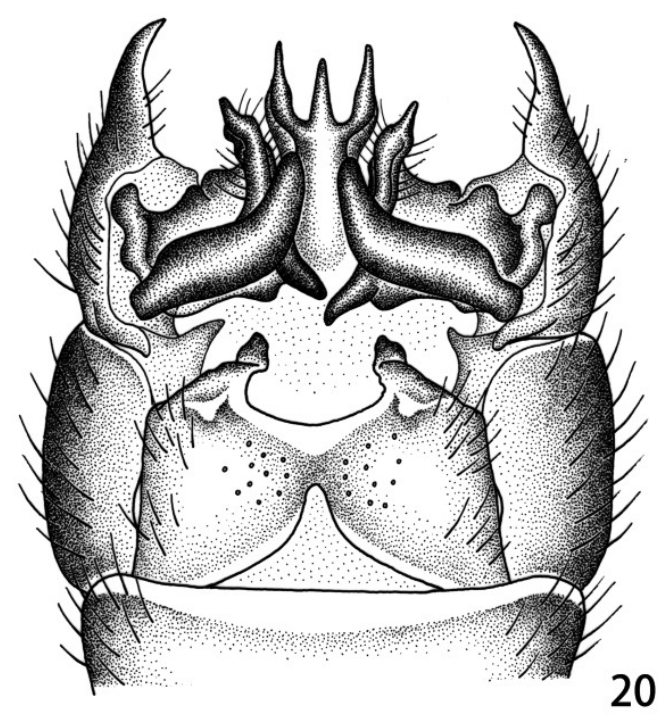

20
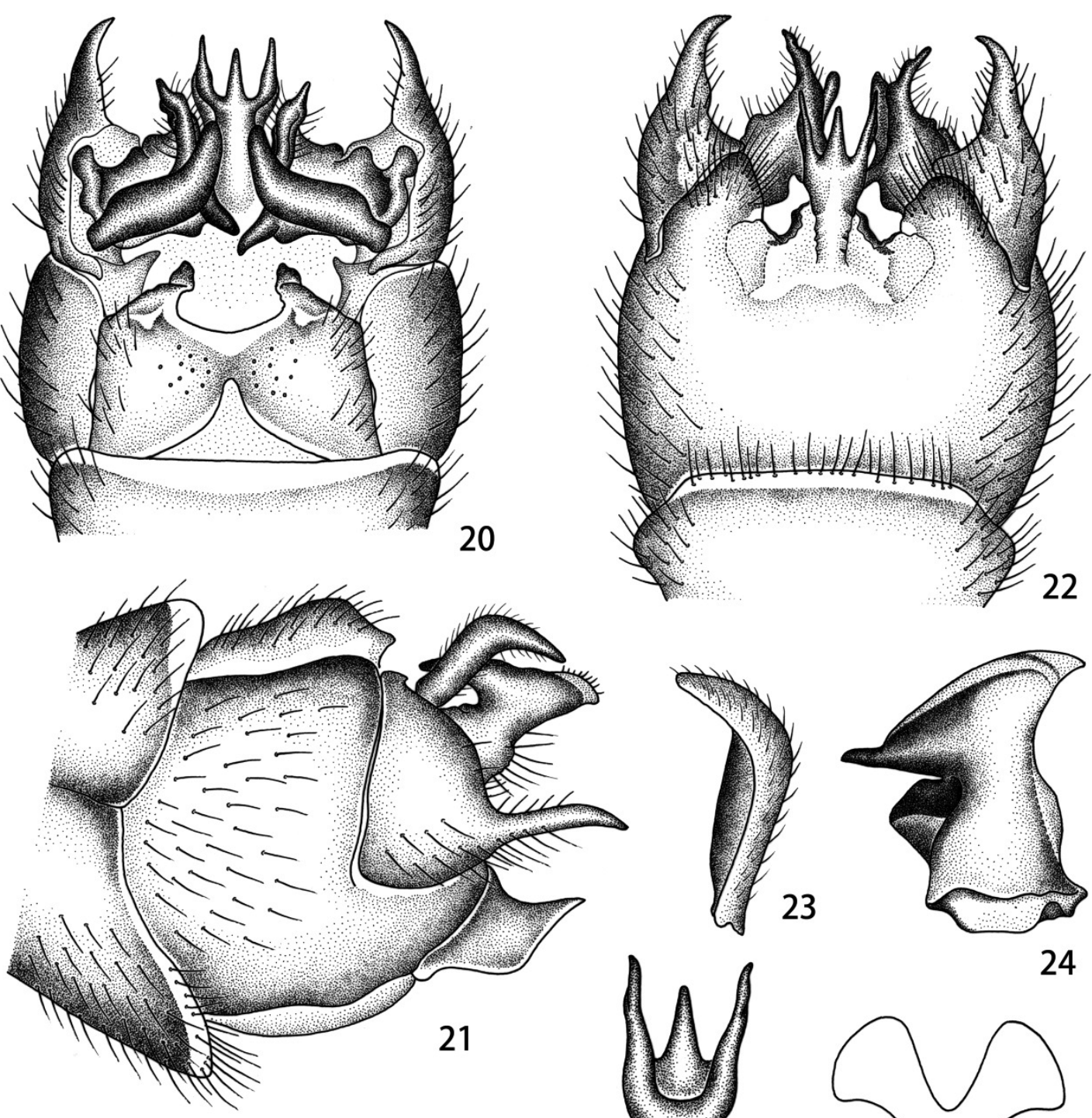

22
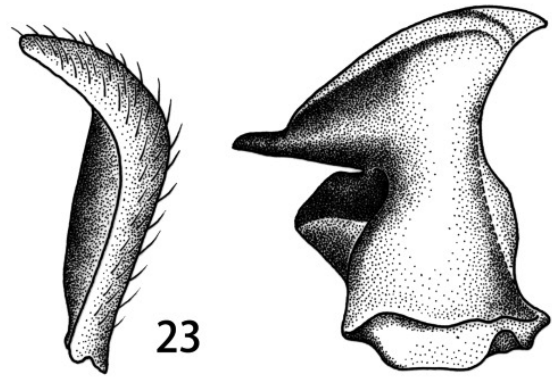

24
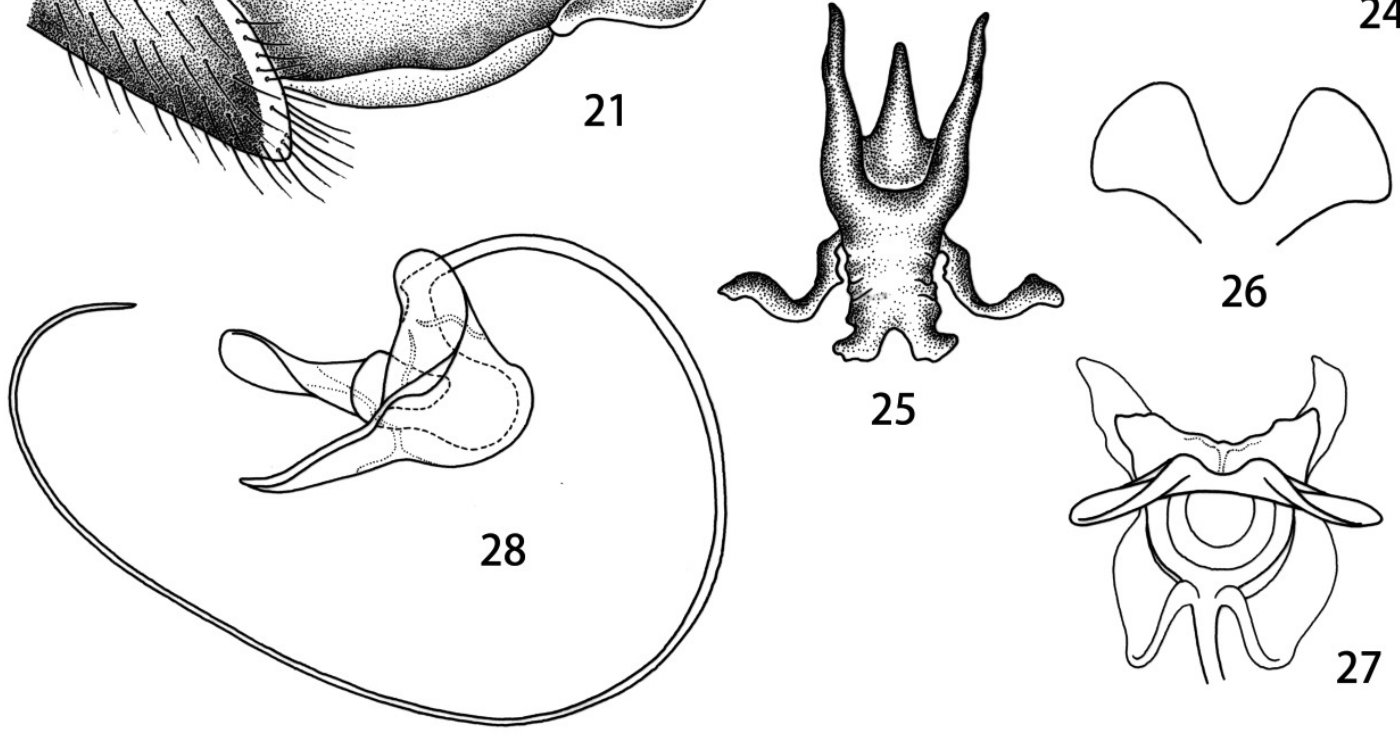

Figs 20-28. Tipula (Vestiplex) alyxis Alexander, 1963, male. 20 - hypopygium, dorsal view; 21 - hypopygium, lateral view; 22 - hypopygium, ventral view; 23 - outer gonostylus, lateral view; 24 - inner gonostylus, lateral view; 25 - adminiculum, ventral view; 26 - compressor apodeme, dorsal view; 27 - semen pump, dorsal view; 28 - semen pump, lateral view. 
Female. Body length $21.2 \mathrm{~mm}$ (excluding antenna, n $=1)$, wing length $18.6 \mathrm{~mm}(\mathrm{n}=1)$, length of antenna 3.2 $\mathrm{mm}(\mathrm{n}=1)$. Generally similar to male in body coloration. Antenna relatively short, if bent backward reaching before base of wing.

Female terminalia. Tergites nine and ten brown. Cercus dark brown, with tip acute and curved dorsally, ventral margin with rough serration (Figs 29-31). Hypovalva short, strongly reduced, terminating in two narrowed lobes, acute apically (Figs 29, 31). Median incision between hypovalvae of almost same depth as posterior margin of sternite eight (Fig. 31). Lateral incision absent. Sternite nine with anterior parts flattened and concave medially (Fig. 31). Spermatheca elliptical.

Distribution. China: Tibet (AlEXANDER 1963b); Yunnan (new record).

\section{Tipula (Vestiplex) guibifida Yang \& Yang, 1992}

(Figs 32-49)

Tipula (Vestiplex) guibifida Yang \& Yang, 1992: 577 (original description)

Tipula (Vestiplex) guibifida: YANG et al. (2006: 447).

Type locality. China, Guizhou, Jiangkou, Fanjingshan.

Material examined. CHINA: TIBET: $3 \hat{\jmath}$, Zhuolonggou, Bomi, 31.v.2019, coll. Q. Men (AQNU). YUNNAN: 1 \ 3 우, Zhangdian near Tuguancun, Lijiang, $27^{\circ} 29^{\prime} 42.0^{\prime \prime} \mathrm{N} 99^{\circ} 53^{\prime} 42.0^{\prime \prime} \mathrm{E}, 3200 \mathrm{~m}, 24-25 . v .2012$, A. Floriani (NRC). Sichuan: 1 \% 9 , Erlang Shan Mountain, Kangding, Ya'an, 29 ${ }^{\circ} 52^{\prime} 23.5^{\prime \prime} \mathrm{N} 102^{\circ} 18^{\prime} 35.6^{\prime \prime} \mathrm{E}, 2100 \mathrm{~m}, 10 .-11 . i v .2010$, A.

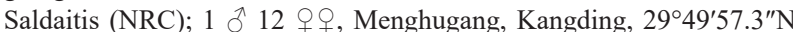
$102^{\circ} 02^{\prime} 49.6^{\prime \prime} \mathrm{E}, 3000 \mathrm{~m}, 12 . i v .2010$, A. Saldaitis (NRC).

Redescription. Male (Figs 32-36). Body length 11.8-16.6 mm (excluding antenna, $\mathrm{n}=8$ ), wing length $14.8-17.2 \mathrm{~mm}$ $(\mathrm{n}=8)$, length of antenna 3.1-3.4 mm $(\mathrm{n}=8)$.
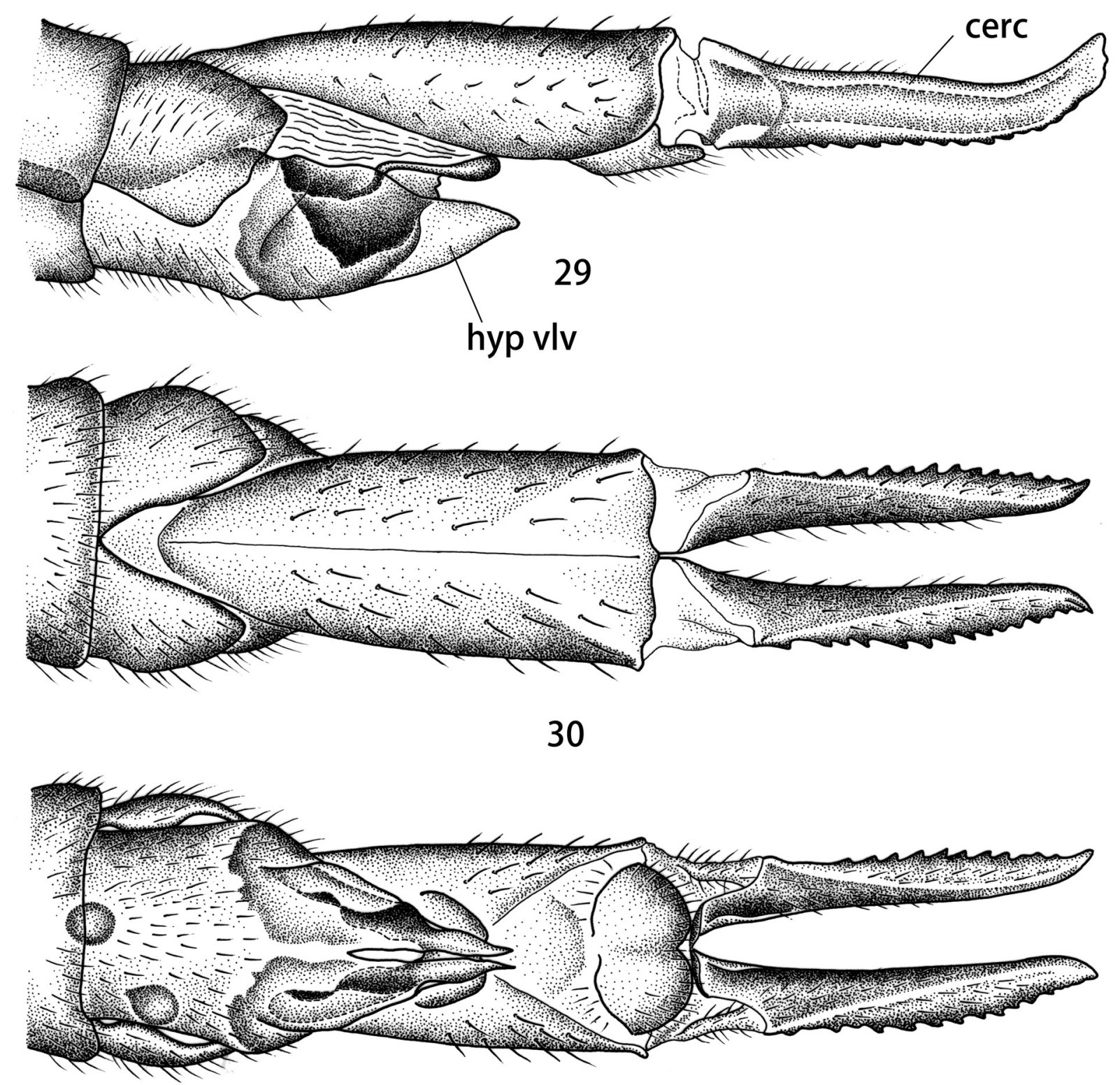

Figs 29-31. Tipula (Vestiplex) alyxis Alexander, 1963, female. 29 - female terminalia, lateral view; 30 - female terminalia, dorsal view; 31 - female terminalia, ventral view. Abbreviations: cerc - cercus; hyp vlv - hypovalva. 
Head. Generally yellowish-brown, vertex and occiput bright with brown linear mark which is pale on vertex, darkened near base of antenna (Fig. 32). Rostrum yellowish-brown except for yellow dorsal surface, nasus yellow, relatively stout, truncated apically. Antenna 13-segmented, if bent backward reaching slightly beyond root of wing. Scape and pedicel yellow. Flagellum with first flagellomere elliptical, light brown, rest of flagellomeres bicolored, enlarged base dark brown, rest yellowish-brown, flagellomeres two to four subequal in length, rest gradually shorter, last segment ball-shaped, basal enlargement with longest verticils subequal in length to corresponding flagellomeres. Whole flagellum densely covered with short and light setae. Palpus with basal three segments yellow, expanded apically, last segment brown, slightly longer than basal three segments together.

Thorax. Pronotum yellow. Prescutum and presutural scutum yellowish-brown with four light brown stripes, median stripes fused at base, separated by yellowish line anteriorly, lateral stripes, marginally suffused with brown on inner side (Fig. 33). Interspace between median and lateral stripes yellowish-brown with light and short setae. Scutum yellowish-brown, each lobe with two brown triangular markings connecting to each other, marginally suffused with dark brown on inner side, between lobes with narrow brown vitta (Fig. 33). Scutellum yellowish-brown with dark median vitta (Fig. 33). Postnotum yellow with dark vitta not extending through postnotum (Fig. 33). Pleuron with anepisternum brown, katepisternum light brown, rest of areas yellow (Fig. 34). Legs with coxae and trochanters yellow, femora with base yellow, gradually changing to brown, tip black, with yellow preapical ring of same length as black tip, tibiae and tarsi entirely black. Halter with stem yellow, knob black. Wing brown, cells c and sc slightly darker than ground color; stigma dark brown, base of stigma with round bright spot; bright band extending backward, crossing bases of cells $r_{1}, r_{3}, r_{4}, r_{5}$ and median area of discal cell, ending at base of cell $\mathrm{m}_{3}$; another bright band extending backward from apical area of cell $\mathrm{c}$ to apical area of bm; other bright areas including bases of bm, cells cua and cup and four bright spots along posterior margin (Fig. 35). Venation: $\mathrm{R}_{1}$ entire, $\mathrm{R}_{2+3+4}$ shorter than $\mathrm{R}_{3}$, $\mathrm{R}_{4}$ slightly shorter than $\mathrm{Rs}, \mathrm{R}_{5}$ curved at apical two fifths, $\mathrm{r}-\mathrm{m}$ subequal in length to base of $\mathrm{R}_{5}$, discal cell narrow, more than 2.8 times longer than petiole of cell $\mathrm{m}_{1}$, cell $\mathrm{m}_{1}$ more than four times longer than its petiole (Fig. 35).

Abdomen. Basal four tergites yellow with brown lateral and median stripes, the latter broad and intermittent, basal four sternites entirely yellow (Fig. 36). Rest of abdominal segments including hypopygium black (Fig. 36).

Male hypopygium. Male hypopygium relatively small. Tergite nine and sternite nine separated except for base (Fig. 37). Tergite nine almost divided by membranous area medially into two lobes, each densely covered with long
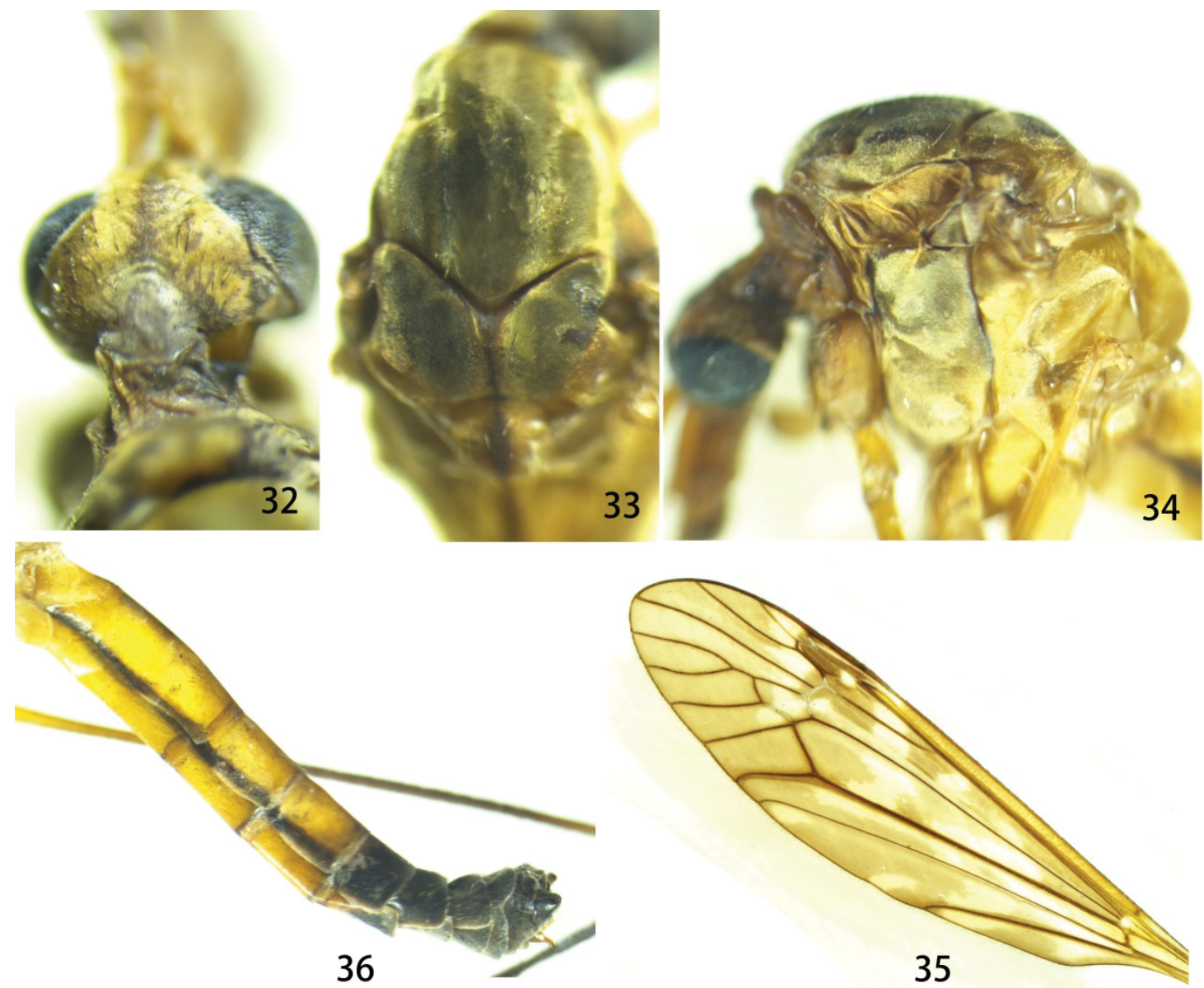

Figs 32-36. Tipula (Vestiplex) guibifida Yang \& Yang, 1992, male. 32 - head, dorsal view; 33 - thorax, dorsal view; 34 - thorax, lateral view; 35 - wing; 36 - abdomen and hypopygium, lateral view. 

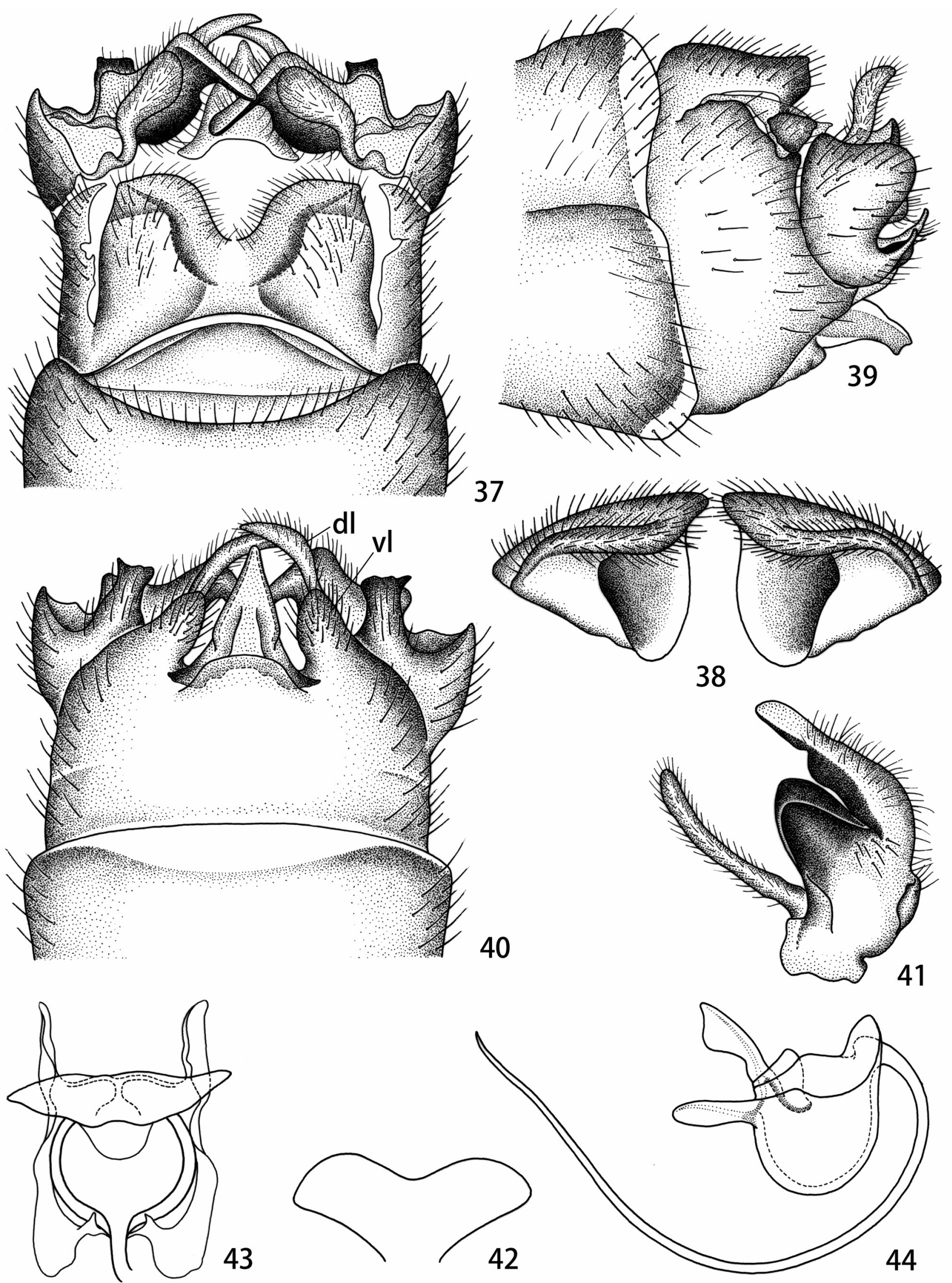

Figs 37-44. Tipula (Vestiplex) guibifida Yang \& Yang, 1992, male. 37 - hypopygium, dorsal view; 38 - tergite nine, caudal view; 39 - hypopygium, lateral view; 40 - hypopygium, ventral view; 41 - left outer and inner gonostyli, lateral view; 42 - compressor apodeme, dorsal view; 43 - semen pump, dorsal view; 44 - semen pump, lateral view. Abbreviations: $\mathrm{dl}$ - dorsal lobe of A9S; vl - ventral lobe of A9S. 
setae on dorsal surface; posterior border of dorsal portion of tergite nine concave into $\mathrm{V}$-shaped notch, with many long setae along its margin; lateral borders relatively straight; ventral portion of tergite nine broad and triangular, with pair of triangular darkened plates (Figs 38, 39). Gonocoxite small, totally separated from sternite nine, bifurcated, upper lobe round, lower lobe curved dorsally in lateral view, truncated apically in dorsal view (Figs 37, 39, 40). Inner gonostylus with dorsal crest narrow, with upper beak elongated, its inner margin suffused with black, lower beak split into two big, rounded, blackened plates (Fig. 41).
Outer gonostylus narrow (Fig. 41). Sternite nine broad, densely covered with setae on lateral surface, appendage of sternite nine possessing thumb-like ventral lobe with many long setae, with dorsal lobe narrow and long, acute apically, pointing inwards (Fig. 39). Adminiculum broad basally with raised margin, narrowed to acute apex in dorsal view, curved ventrad, truncated apically in lateral view (Figs 39, 40). Median sclerite of adminiculum conspicuous (Fig. 41). Semen pump with compressor apodeme fan-shaped, shallowlly emarginated medially (Fig. 42). Posterior immovable apodeme with paired arms straight,
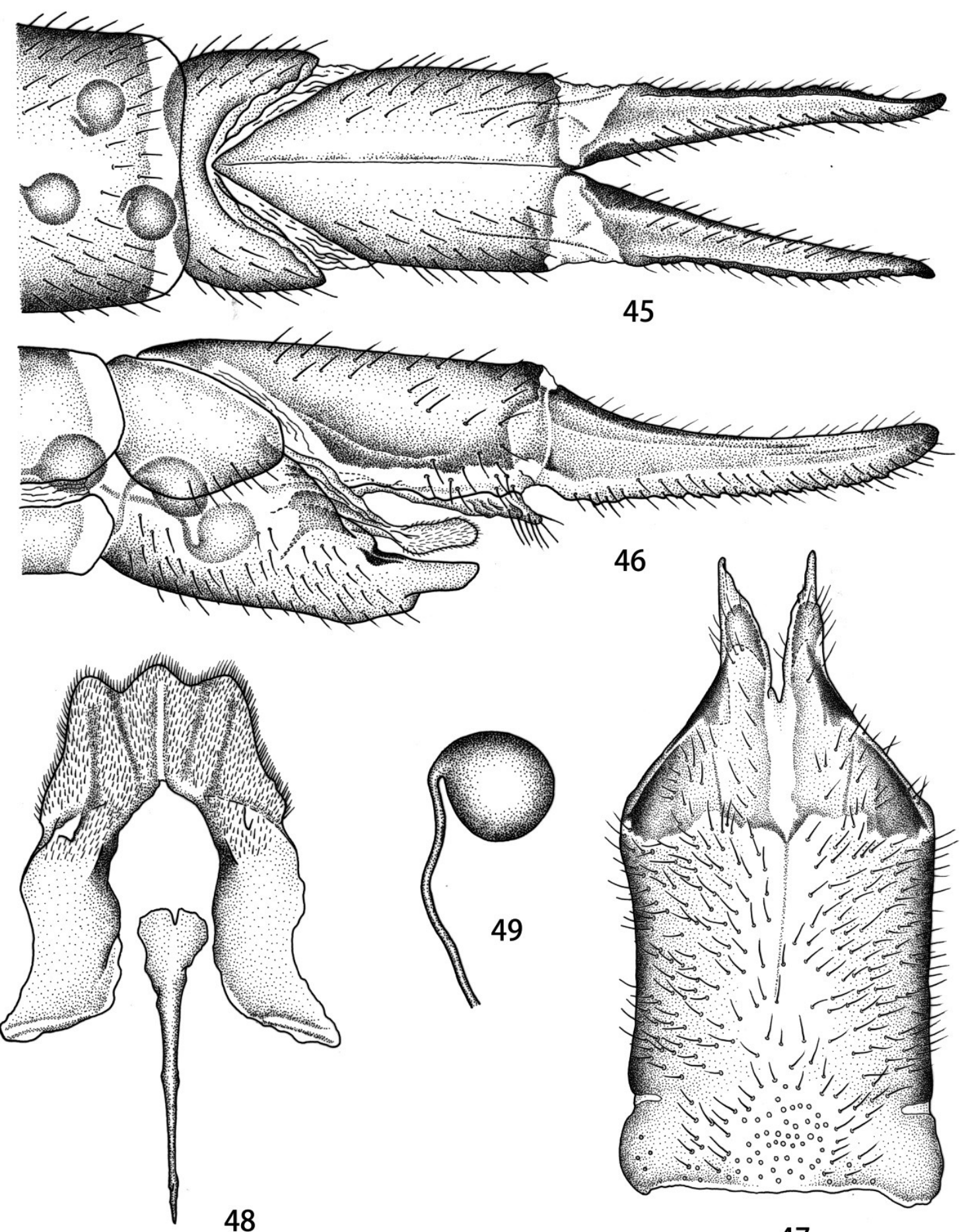

47

Figs 45-49. Tipula (Vestiplex) guibifida Yang \& Yang, 1992, female. 45 - female terminalia, dorsal view; 46 - female terminalia, lateral view; 47 - sternite eight with hypovalvae, ventral view; 48 - sternite nine with furca, dorsal view; 49 - spermatheca. 
terminating into obtuse apex in lateral view (Figs 43, 44). Anterior immovable apodeme broad, flattened, elongated in dorsal view (Fig. 43). Aedeagus relatively thick, gradually narrowed to apex, more than 3.5 times longer than semen pump (Fig. 44).

Female. Body length 17.0-21.9 mm (excluding antenna, $\mathrm{n}=17)$, wing length $15.2-19.6 \mathrm{~mm}(\mathrm{n}=17)$, length of antenna $2.5-3.0 \mathrm{~mm}(\mathrm{n}=17)$. Generally similar to male in body coloration. Antenna relatively short, if bent backward reaching beyond pronotum.

Female terminalia. Tergites nine and ten shining light brown. Cercus light brown, relatively short, nearly straight with tip rounded. Ventral and dorsal margins with small, distinct serration.

Hypovalva in shape of short pale-yellow plates, terminating into narrowed tip (Figs 45, 46). Base of hypovalvae covered by posterior margin of sternite nine, the latter lightly extended, rounded at tip and provided with setae. Median incision between hypovalvae of almost same depth as posterior margin of sternite eight (Fig. 47). Lateral incision absent. Sternite nine with anterior parts flattened (Fig. 48). Posterior part of sternite nine covered with short filaments, shovel-shaped, medially with shallow groove, posterior margin with median triangle projection, laterally with incisions (Fig. 48). Furca elongated, in shape of narrow stripe, anteriorly flattened (Fig. 48). Spermatheca spherical, lightly broadened at base (Fig. 49).
Distribution. China: Guizhou (YANG \& YANG 1992); Sichuan (new record), Tibet (new record), Yunnan (new record).

\section{Tipula (Vestiplex) himalayensis Brunetti, 1911 (Figs 50-67)}

Tipula himalayensis Brunetti, 1911: 252 (original description). Tipula (Vestiplex) himalayensis: Edwards (1931: 80); Alexander (1935a: 119); AlEXANDER (1942: 41; lectotype designation); ALEXANDER (1963a: 23); ALEXANDER \& ALEXANDER (1973: 63); JOSEPH (1974: 269); Dutta et al. (1997: 17); Mitra \& Bhattacharya (2010: 362); Starkevich \& Podenas (2011: 276); Pilipenko et al. (2019: 14). Tipula (Vestiplex) subreposita Alexander, 1942: 39 (original description). Tipula (Vestiplex) subreposita: AleXANDER (1953: 343). Synonymy after AlEXANDER (1963b).

Type locality. India, West Bengal, Darjeeling.

Type material examined. PARALECTOTYPE: $1 \hat{\jmath}$, INDIA: E. Himalayas, Darjeeling, 6000 ft., 22.ix.1908, coll. E. Brunetti (antenna, leg, wing and genitalia on slide) (USNM). PARALECTOTYPES: $3 \hat{\jmath}$, INDIA: Darjeeling, 20.x.1905, coll. E. Brunetti (BMNH; No. 246063-246065); 1 q, INDIA: Darjeeling, 10.-16.x.1905, coll. E. Brunetti (BMNH; No. 246062).

Additional material examined. CHINA: YunNAN: $1 \hat{\jmath}$, Zhanatong, Bingzhongluo, Gongshan County, 11.vi.2019, coll. Q. Men \& L. Lv (AQNU); $2 \AA \widehat{\jmath}$, Gongdangshenshan, Bingzhongluo, Gongshan County, 12.vi.2019, coll. Q. Men \& L. Lv (AQNU); 1 ふै, Bapo, Dulongjiang, Gongshan County, 15.vi.2019, coll. Q. Men Qiulei, L. Lv (AQNU); 2 $\widehat{\jmath} \partial^{2}$, Laomudeng, Fugong County, 19.vi.2019, coll. Q. Men \& L. Lv (AQNU); 1 §, Pianma, Lushui County, 19.vi.2019, coll. Q. Men \& L. Lv (AQNU). 4 ふึ 2 웅, Nu Jiang valley, road Lushui/Gulang, N25 58'15", E98 47'40", 2000 m, 13.v.2018, R. Butvila \& A. Saldaitis
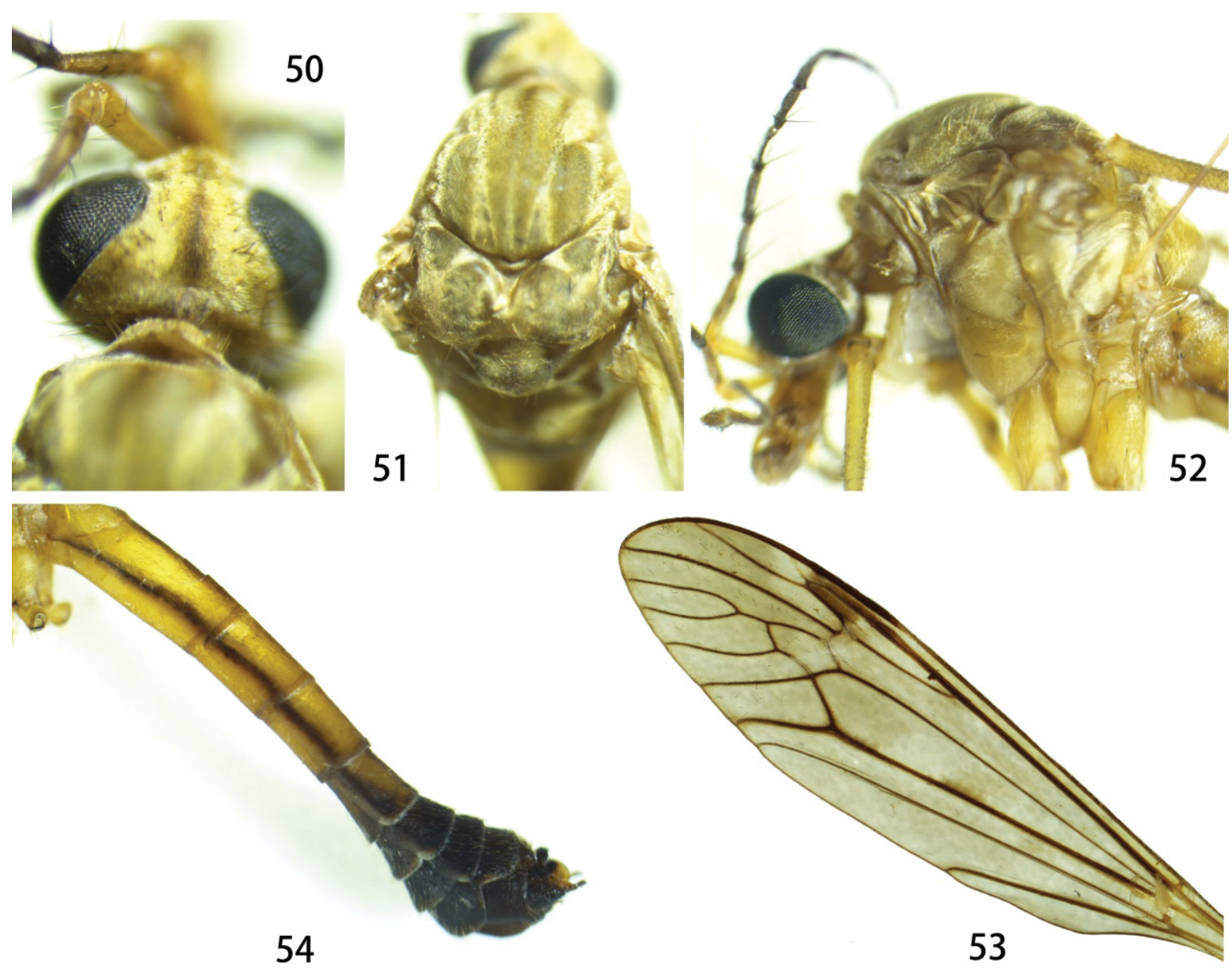

Figs 50-54. Tipula (Vestiplex) himalayensis Brunetti, 1911, male. 50 - head, dorsal view; 51 - thorax, dorsal view; 52 - thorax, lateral view; 53 - wing; 54 - abdomen and hypopygium, lateral view. 


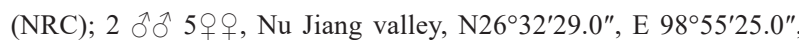

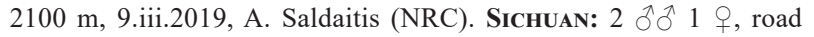

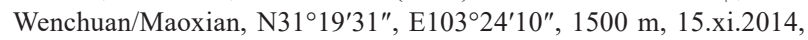
A. Floriani \& A. Saldaitis (NRC).

Redescription. Male (Figs 50-54). Body length 11.6-11.9 mm (excluding antenna, $\mathrm{n}=14$ ), wing length $14.2-14.8$ mm ( $\mathrm{n}=14)$, length of antenna 4.2-4.8 mm $(\mathrm{n}=14)$. General body coloration yellow.

Head. Generally yellow, vertex and occiput with dark brown linear mark. Tubercle distinct in lateral view (Fig. 50). Rostrum yellow in dorsal part, yellowish-brown in ventral part, nasus yellow, slightly curved, short and stout,

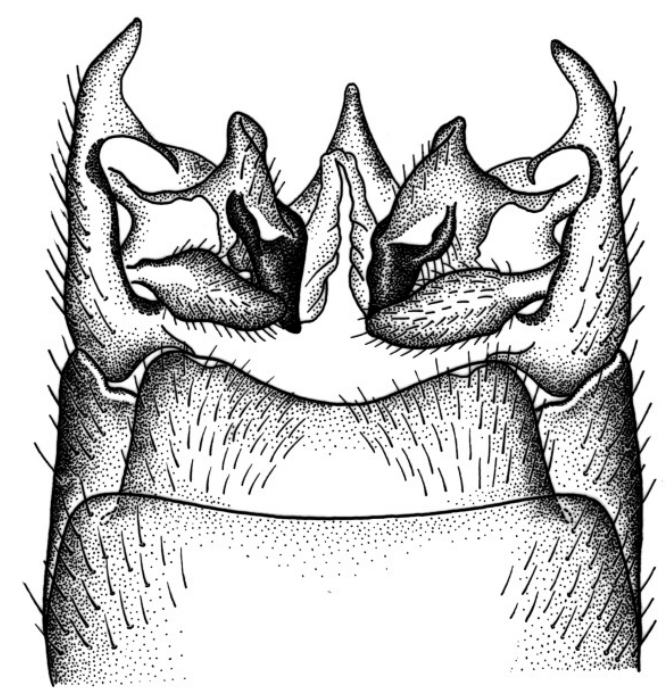

55

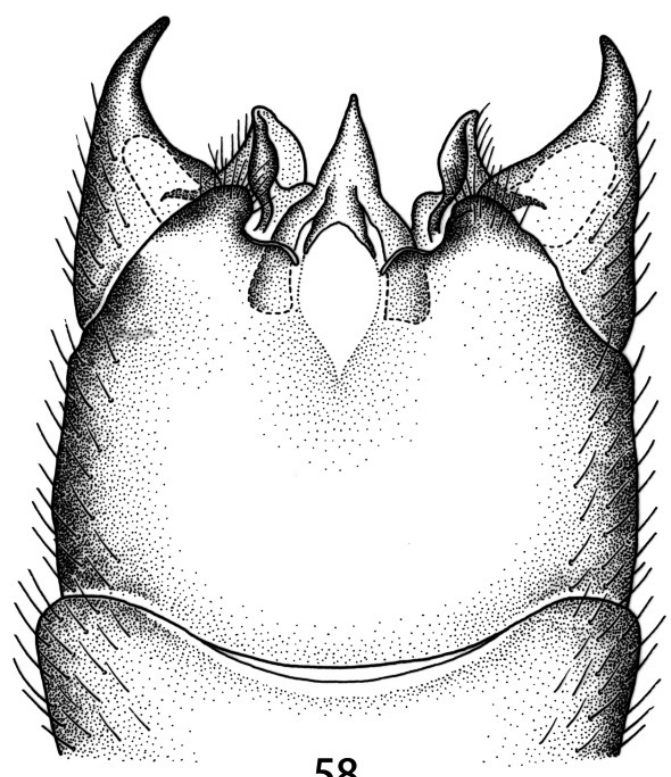

58
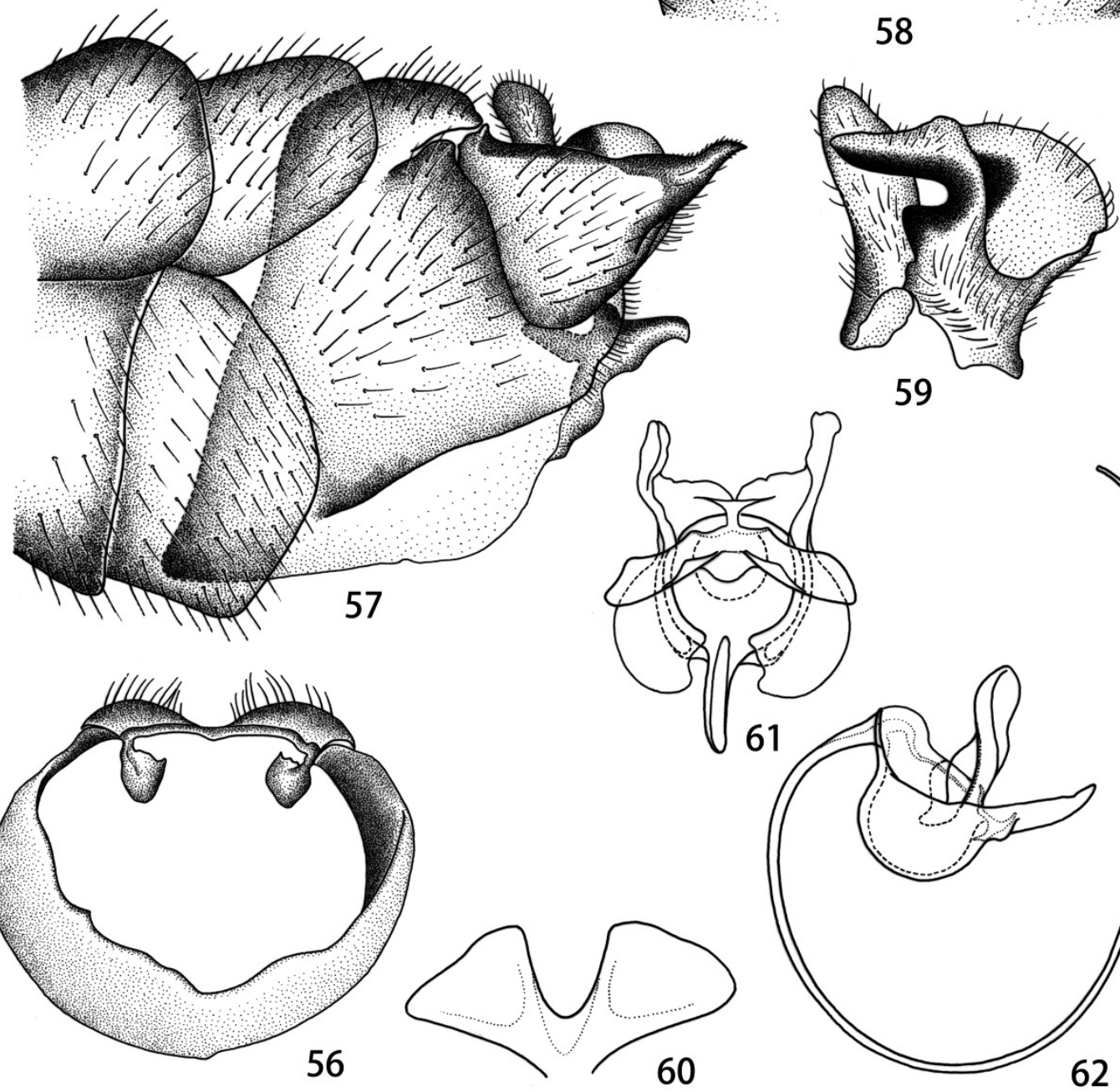

59
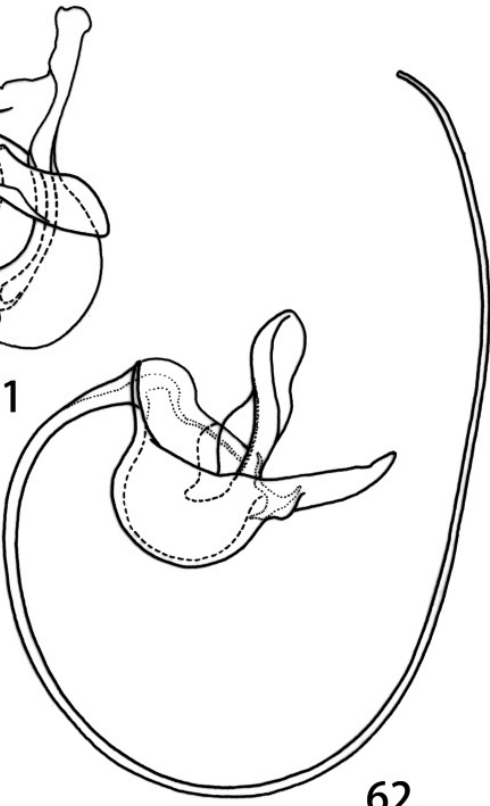

Figs 55-62. Tipula (Vestiplex) himalayensis Brunetti, 1911, male. 55 - hypopygium, dorsal view; 56 - tergite nine and sternite nine, caudal view; 57 - hypopygium, lateral view; 58 - hypopygium, ventral view; 59 - left outer and inner gonostyli, lateral view; 60 - compressor apodeme, dorsal view; 61 - semen pump, dorsal view; 62 - semen pump, lateral view. 
densely covered with black setae. Antenna 13-segmented, if bent backward reaching base of $2^{\text {nd }}$ abdominal segment. Scape and pedicel yellow, flagellum with first flagellomere expanded medially, yellowish, rest of flagellomeres black. Apical flagellomere very small, oval. Each flagellomere except for first with basal enlargement, longest verticils subequal in length to their corresponding flagellomeres. Whole flagellum densely covered with short and light setae. Palpus with basal two segments light brown, rest of segments yellow, slightly longer than basal three segments together.

Thorax. Pronotum yellow, brownish in middle and lateral areas. Prescutum and presutural scutum yellow with four greyish-brown stripes, median stripes narrowed at base and gradually expanded to obtuse apex, merging apically and possessing black median vitta in apical third, lateral stripes rounded apically, darker in coloration on inner side
(Fig. 51). Interspace between median and lateral stripes yellowish with light and short setae. Scutum yellow, each lobe with two brown triangular markings connecting to each other (Fig. 51). Scutellum yellow, with dark median vitta. Postnotum yellow with thin dark vitta. Pleuron entirely yellow (Fig. 52). Legs with coxae, trochanters and basal fifth of femora yellow, rest of femora brown with tip black, with yellow preapical ring, tibiae and tarsi entirely black. Halter with stem yellow, knob yellowish-brown. Wing light brown, variegated by light areas, including apical area of cell $\mathrm{c}$, median area of $1^{\text {st }}$ cell of $\mathrm{r}_{1}$, base of stigma, light band across apical area of cell $r_{1}$, base of cells $r_{3}, r_{4}$ and $\mathrm{r}_{5}$; other light area including base and apical areas of bm; stigma dark brown (Fig. 53). Venation: $R_{1}$ atrophied in basal two thirds, $\mathrm{R}_{2+3+4}$ longer than $\mathrm{R}_{3}, \mathrm{R}_{4}$ subequal in length to Rs, $R_{5}$ curved in apical half, $r-m$ subequal in length to base of $R_{5}$, discal cell narrow, of almost same length as
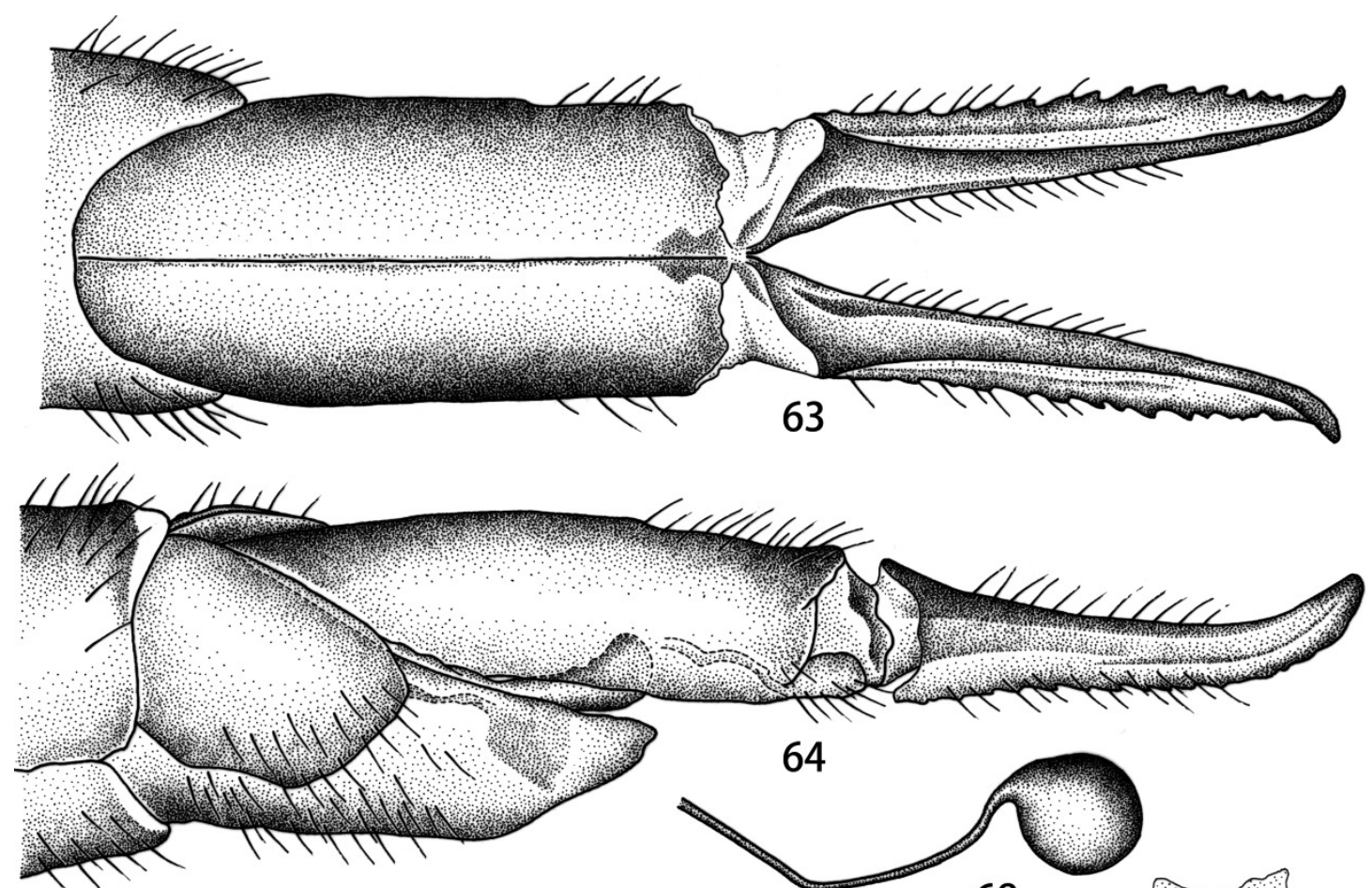

68
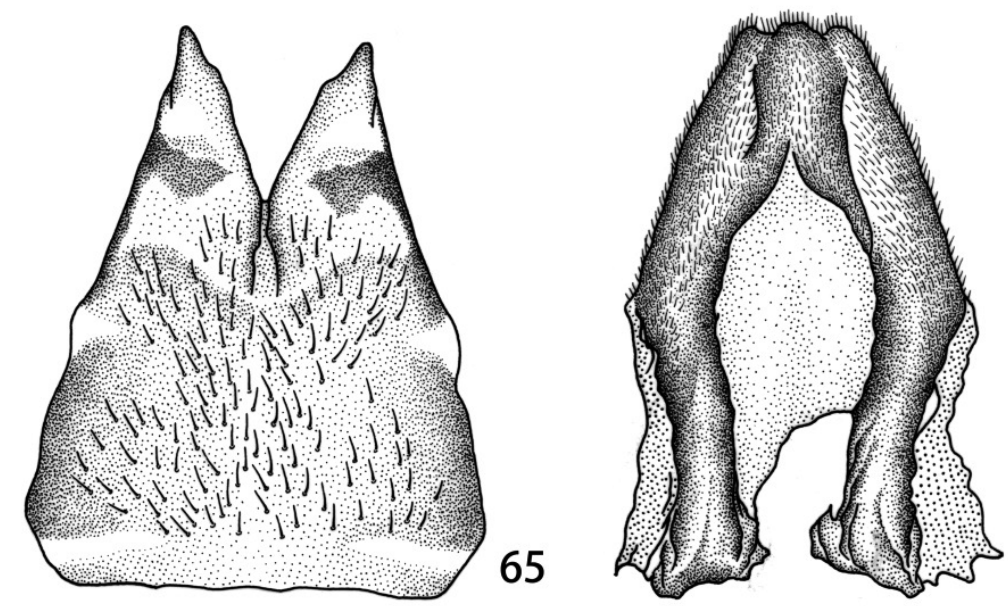

66

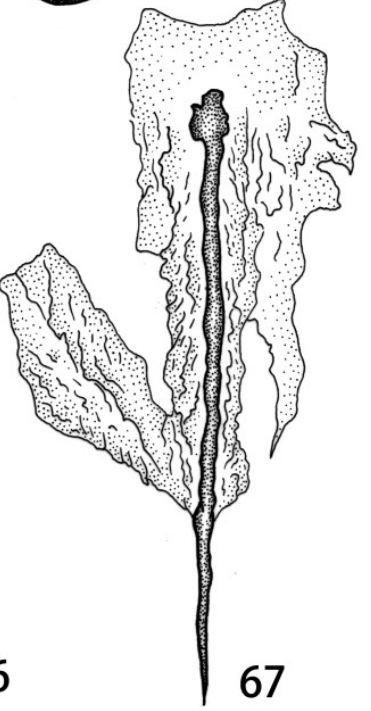

Figs 63-68. Tipula (Vestiplex) himalayensis Brunetti, 1911, female. 63 - female terminalia, dorsal view; 64 - female terminalia, lateral view; 65 - sternite eight with hypovalvae, ventral view; 66 - sternite nine, dorsal view; 67 - furca, dorsal view; 68 - spermatheca. 
petiole of cell $\mathrm{m}_{1}$, cell $\mathrm{m}_{1}$ nearly three times longer than its petiole (Fig. 53).

Abdomen. Basal five abdominal segments yellow with brown lateral and median stripes, rest of abdominal segments including hypopygium black (Fig. 54).

Hypopygium. Male hypopygium with tergite nine and sternite nine separated apically (Fig. 55). Tergite nine divided mid-dorsally by pale region, dorsal portion shallowly emarginated at posterior border, straight laterally, apical half densely covered with setae (Figs 55, 56). Ventral portion of tergite nine reduced into narrow yellow plate terminating into two small oval lobes (Fig. 56). Gonocoxite broad basally, producing into powerful spine directed inward, with many long setae on lateral surface (Figs 55, 57, 58). Outer gonostylus flattened, blackened, broad medially, densely covered with short setae (Fig. 59). Inner gonostylus with upper beak relatively stout, lower beak obtuse, black stripe suffused along margins of beaks (Fig. 59). Sternite nine concave medially, appendage of sternite nine with ventral lobe rounded and densely covered with long setae (Fig. 58). Adminiculum broad basally and narrowed to acute apex in dorsal view, sinuate at ventral margin in lateral view; median sclerite conspicuous (Figs 57, 58). Semen pump with compressor apodeme fan-shaped, medially with deeply V-shaped notch, each arm broad and truncated apically, slightly longer than posterior immovable apodeme (Fig. 60). Posterior immovable apodeme with paired arms slightly straight, terminating into sharp apex in lateral view (Figs $61,62)$. Anterior immovable apodeme broad, flattened, rounded in dorsal view (Fig. 62). Aedeagus thick at base, gradually narrowed to apex, more than 4.5 times longer than semen pump (Fig. 62).

Female. Body length 19.1-22.7 mm (excluding antenna, $n=9)$, wing length 17.4-20.1 mm $(n=9)$, length of antenna $2.7-3.1 \mathrm{~mm}(\mathrm{n}=9)$. Generally similar to male in body coloration. Antenna relatively short, if bent backward reaching before base of wing.

Female terminalia. Tergites nine and ten shining brown. Cercus brown, with tip narrowed and curved dorsally, ventral margin with rough serration (Figs 63, 64). Hypovalva short, strongly reduced, terminating in two narrowed pale plates, acute apically (Figs 64, 65). Median incision between hypovalvae almost same depth to posterior margin of sternite eight (Fig. 65). Lateral incision absent. Sternite nine with anterior parts flattened and concave medially (Fig. 66). Posterior part of sternite nine covered with short filaments, shovel-shaped, medially with groove, posterior margin medially inconspicuously convex, laterally with very small incisions (Fig. 66). Anterior parts of sternite nine lightly curved in middle length. Furca in shape of narrow filament (Fig. 67). Spermatheca spherical (Fig. 68).

Distribution. China: Sichuan (new record); Yunnan (SAvchenko 1960), Tibet (Alexander 1963a). India: Arunachal Pradesh (Starkevich \& Podenas 2011), Himachal Pradesh (Starkevich \& Podenas 2011), Sikkim (Starkevich \& Podenas 2011), Uttarakhand (Mitra \& BhatTaCHarya 2010), West Bengal (AleXANDER 1942;
BrunetTi 1911; DutTA et al. 1997; JoSEPH 1974; Mitra \& Bhattacharya 2010). Myanmar (Starkevich \& Podenas 2011). Vietnam (EDWARDS 1926).

\section{Tipula (Vestiplex) quasimarmoratipennis Brunetti, 1912 \\ (Figs 69-82)}

Tipula quasimarmoratipennis Brunetti, 1912: 320 (original description). Tipula quasimarmoratipennis: BRUNETTI (1918: 262); EDWARDS (1924: 305).

Tipula (Vestiplex) quasimarmoratipennis: AleXANDER (1935a: 119); Alexander (1942: 46); Alexander (1963a: 23); Alexander \& ALEXANDER (1973: 64); JoSEPH (1974: 271).

Type locality. India, West Bengal, Darjeeling.

Material examined. CHINA: YunNAN: $1 \hat{\jmath}$, Zhanatong, Bingzhongluo, Gongshan County, 11.vi.2019, coll. Q. Men \& L. Lv (AQNU); 1 ふै, Gongdangshenshan, Bingzhongluo, Gongshan County, 12.vi.2019, coll. Q. Men \& L. Lv (AQNU). INDIA: MEgHALAYA: $1 \hat{\jmath}$, above Tura, Garo hills, 3500-3900 ft., ix.1917, coll. S.W. Kemp (BMNH); 1 \%, Shilong, iv.1920, coll. T. B. Fletcher (BMNH); 1 §ै, Shillong, 5000 ft., 30.v.18, coll. T. B. Fletcher (BMNH); 2 ふै่, Shillong, ix.-x.1918, coll. T. B. Fletcher (BMNH); 1 §ै, Assam, Cherrapunyi, 4400 ft., 12.x.1918, S. W.

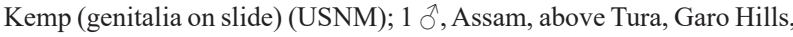
3500-3900 ft., ix.1917, S. W. Kemp, Homotype, Edwards (USNM), antenna, leg, wing and genitalia on two slides (USNM)

Redescription. Male (Figs 69-73). Body length 14.0-14.3 mm (excluding antenna, $\mathrm{n}=2$ ), wing length 19.8-20.1 mm $(\mathrm{n}=2)$, length of antenna: $3.7-3.9 \mathrm{~mm}(\mathrm{n}=2)$.

Head. Generally greyish-brown, vertex and occiput with dark brown linear mark (Fig. 69). Rostrum yellowish-brown, nasus yellow, very stout, acute at apex, densely covered with black setae. Antenna 13-segmented, if bent backward almost reaching base of $1^{\text {st }}$ abdominal segment. Scape and pedicel yellow, first flagellomere expanded in apical half, yellowish, rest of flagellomeres enlarged at base, dark brown. Apical flagellomere light brown, distinctly shorter than preceding flagellomere. Basal enlargement with longest verticils distinctly longer than corresponding flagellomeres. Whole flagellum densely covered with short and light setae. Palpus with first segment brown, rest of segments lighter in coloration, last segment significantly longer than basal three segments together.

Thorax. Pronotum yellowish-brown with some dark regions medially and laterally. Prescutum and presutural scutum greyish-brown with four brown stripes, median stripes narrowed at base and gradually expanded to rounded apex, merging at both ends, lateral stripes rounded apically, marginally suffused with brown on inner sides (Fig. 70). Interspace between median and lateral stripes yellowish with light and short setae. Postsutural scutum greyish-brown, each lobe with two brown triangular markings (Fig. 70). Scutellum greyish-brown with brown median vitta. Postnotum greyish-brown with brown median vitta. Pleuron entirely yellow (Fig. 71). Legs with coxae, trochanters and basal fourth of femora yellow, rest of femora gradually changing to brown at tip, tibiae and tarsi entirely brown. Halter with stem yellow, knob brown. Wing light brown, cell sc slightly darker than ground color, variegated by light areas including apical area of cell c, median area of $1^{\text {st }}$ cell of $r_{1}$, base of stigma, light band across apical area of cell $r_{1}$, base of cells $r_{3}, r_{4}$ and $r_{5}$, and median area 
of discal cell; other light areas including base and apical areas of bm, apical area of cell cua (Fig. 72). Venation: $R_{1}$ atrophied in basal half, $R_{2+3+4}$ significantly shorter than $\mathrm{R}_{3}, \mathrm{R}_{4}$ distinctly shorter than $\mathrm{Rs}, \mathrm{R}_{5}$ curved in apical half, $\mathrm{r}-\mathrm{m}$ half the length of $\mathrm{R}_{5}$ base, discal cell narrow, longer than petiole of cell $\mathrm{m}_{1}$, cell $\mathrm{m}_{1} 2.9$ times longer than its petiole (Fig. 72).

Abdomen. Basal four abdominal segments yellow with brown lateral stripes, median stripe brown and intermittent, and rest of abdominal segments including hypopygium dark brown (Fig. 73).

Hypopygium. Male hypopygium with tergite nine separated from sternite nine except for base (Fig. 74). Tergite nine divided at midline by pale membrane (Figs 74, 75). Dorsal portion of tergite nine covered with setae, posterior margin with pair of thumb-shaped lobes directed caudad and densely covered with setae (Fig. 74). Ventral portion of tergite nine yellow with pair of blackened, long, narrow, microscopically serrated lobes (Fig. 75). Gonocoxite totally divided to sternite nine by suture, base massive, apically terminating into two spines, outer one curved dorsally, inner one directed inwards (Figs 74-77). Outer gonostylus narrow and elongated, rounded apically (Fig. 78). Inner gonostylus elongated, dark in coloration, relatively narrow plate (Fig. 78), upper beak short, black and narrowed at tip, lower beak in shape of rounded lobe, dorsal crest with margin sloping (Fig. 78). Sternite nine broad, densely covered with setae on lateral surface, medially with massive membranous area strongly produced caudad in lateral view, appendage of sternite nine possessing ventral lobe broad, thumb-like, sparsely equipped with long setae, with dorsal lobe long and curved, broad basally, gradually narrowed to black sharp terminal, pointed inwards (Figs 77, 79). Adminiculum rounded apically with median sclerite oblong (Fig. 77). Semen pump with compressor apodeme fan-shaped, medially with deep V-shaped notch, distinctly longer than posterior immovable apodeme (Fig. 80). Posterior immovable apodeme with paired arms slightly curved dorsally, S-shaped, terminating into acute apex in lateral view (Figs 81, 82). Anterior immovable apodeme broad, rounded, flattened in dorsal view (Fig. 82). Aedeagus thick, almost same thickness, broad at apex, with small hook, aedeagus about 2.5 times longer than semen pump (Fig. 82).

Distribution. China: Yunnan (new country record). India: Meghalaya, West Bengal (BRUNeTti 1912, 1918; JOSEPH 1974).
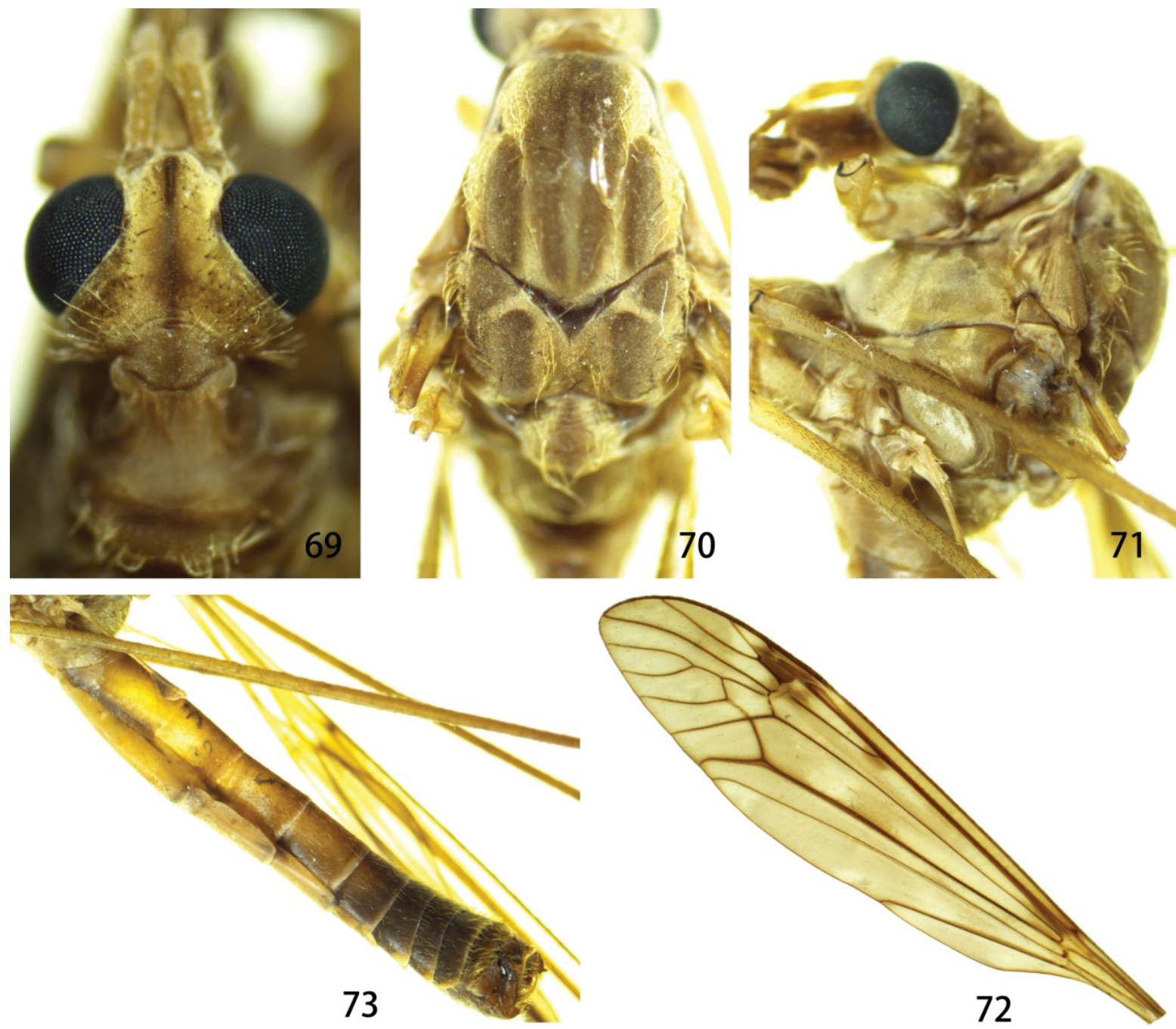

Figs 69-73. Tipula (Vestiplex) quasimarmoratipennis Brunetti, 1912, male. 69 - head, dorsal view; 70 - thorax, dorsal view; 71 - thorax, lateral view; 72 - wing; 73 - abdomen and hypopygium, lateral view. 


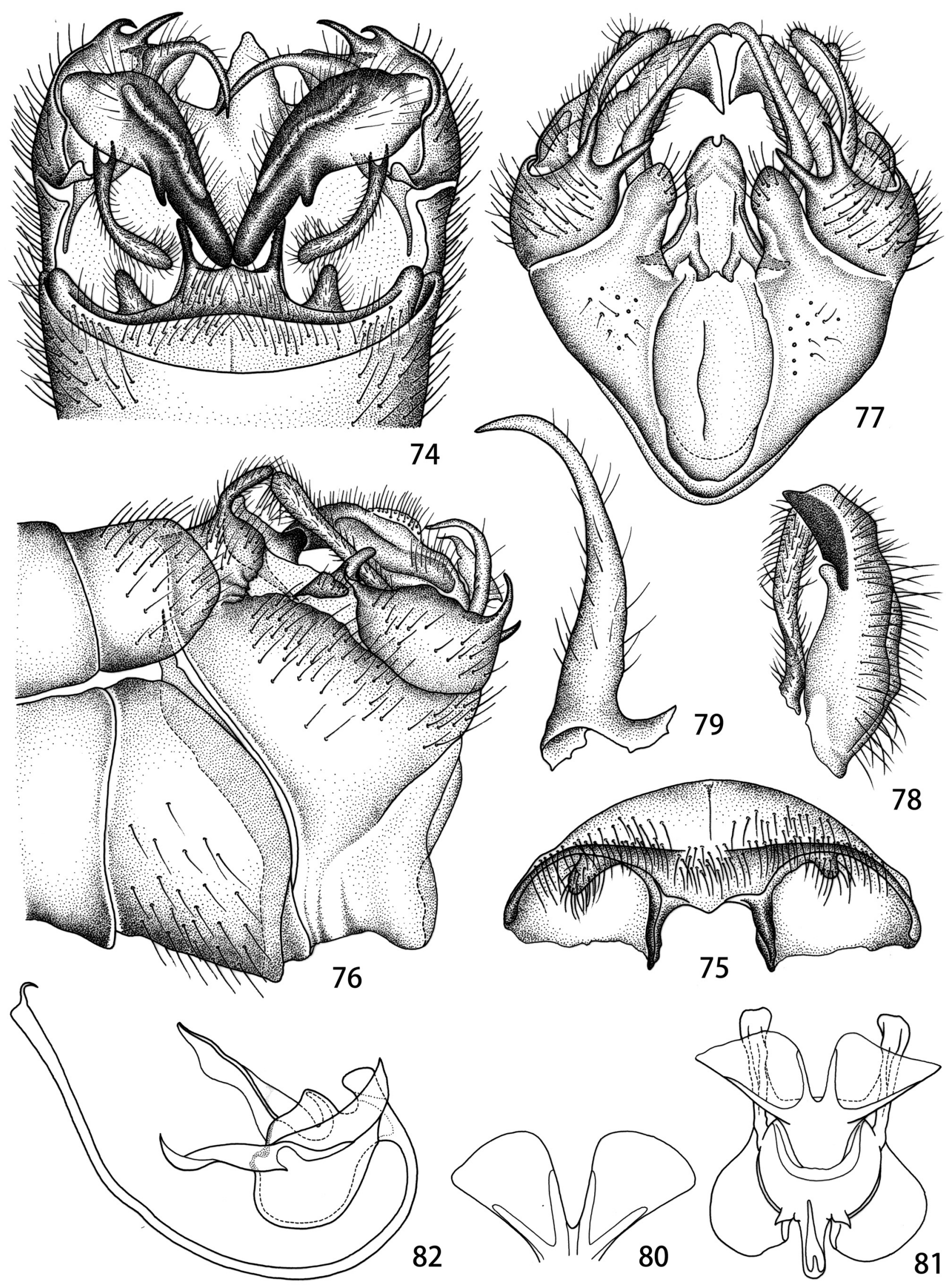

Figs 74-82. Tipula (Vestiplex) quasimarmoratipennis Brunetti, 1912, male. 74 - hypopygium, dorsal view; 75 - tergite nine, caudal view; 76 - hypopygium, lateral view; 77 - hypopygium, ventral view; 78 - left outer and inner gonostyli, lateral view; 79 - dorsal lobe of A9S; 80 - compressor apodeme, dorsal view; 81 - semen pump, dorsal view; 82 - semen pump, lateral view. 
Remark. The identification of this species is based on a dissected male from BMNH and dissected males from USNM (genitalia mounted on slides by C. P. Alexander) identified by F. W. Edwards and marked as "homotypes". Alexander while describing the paratype female from Kurseong expressed doubt whether the specimen is conspecific with the holotype collected from Darjeeling, India (ALEXANDER 1942). JoSEPH (1974) when revising Brunetti's types in the collection of the Zoological Survey of India, noticed that other paratypes (females) show some variations. Additional fresh material of females in copula is needed as comparative base for a proper revision of the female from the type series.

\section{Tipula (Vestiplex) reposita Walker, 1848 (Figs 83-95)}

Tipula reposita Walker, 1848: 67 (original description).

Tipula reposita: EDWARDS (1926: 53).

Tipula (Vestiplex) reposita: EDWARDS (1931: 80); ALEXANDER (1933: 518);

Alexander (1935a: 119); Alexander (1963a: 23); Alexander \& AleXANDer (1973: 64); Joseph (1974: 269); STARKEVICH et al. (2015: 122); PilipenKo et al. (2019: 14).

Tipula (unplaced) reposita: ZHANG et al. (2020: 24).

Tipula brevis Brunetti, 1918: 270 (original description). Synonymy after EDWARDS (1924: 307)
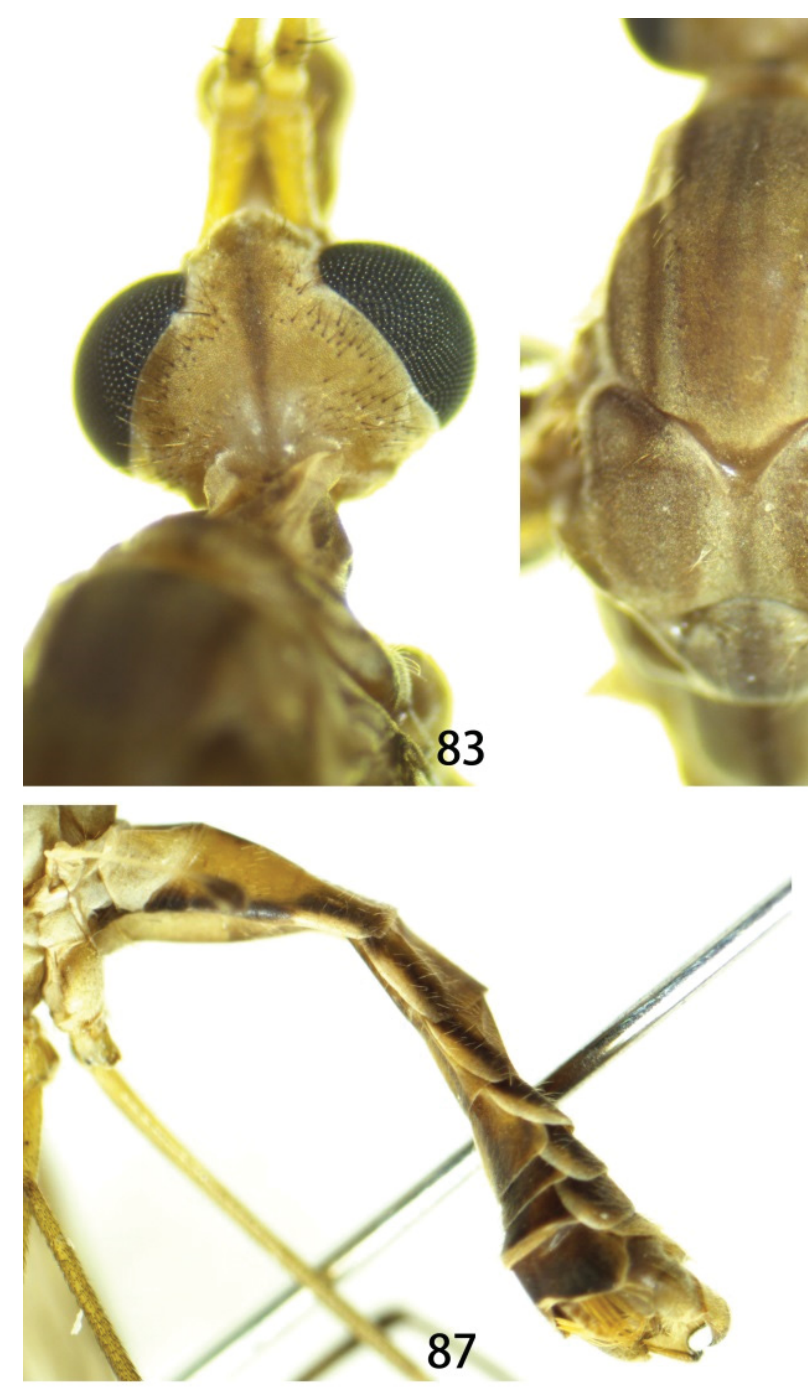

Tipula (Vestiplex) brevis: JoSEPH (1974: 269).

Tipula (Oreomyza) cladomera Alexander, 1936: 230. Synonymised by ZHANG et al. (2020: 24).

Tipula cladomera: SAVCHENKo (1964: 485; as Tipula incertae sedis); Oosterbroek \& TheOwALd (1992: 167; unplaced species of Tipula).

Type locality. Nepal.

Type material examined. Tipula (Vestiplex) reposita: Syntype: $q$, Hardwicke Bequest / One of Walkers series so named. Edw / Tipula reposita, + Walker (Type) (BMNH; No. 246061).

Tipula cladomera: Holotype: $\curvearrowright$, CHINA: SichuAn: Wan-hsien (= Chongqing: Wanzhou, viz ZHANG et al. 2020), 1921.ix.1921 (antenna, leg, wing, parts of genitalia: gonocoxite, inner and outer gonostyli, adminiculum on slide) (USNM).

Additional material examined. CHINA: YunNAN: $1 \hat{\sigma}$, Zhanatong, Bingzhongluo, Gongshan County, 11.vi.2019, coll. Q. Men \& L. Lv (AQNU); CHINA: YunNan: $1 \hat{\jmath}$, Laomudeng, Fugong County, 19.vi.2019, leg. Q. Men \& L. Lv (AQNU).

Redescription. Male (Figs 83-87). Body length 10.4-10.6 $\mathrm{mm}$ (excluding antenna, $\mathrm{n}=2$ ), wing length $15.5-15.7 \mathrm{~mm}$ $(\mathrm{n}=3)$, length of antenna 3.8-4.0 $\mathrm{mm}(\mathrm{n}=3)$.

Head. Generally yellowish-brown, vertex and occiput bright with brown linear mark (Fig. 83). Rostrum yellowish-brown, nasus yellow, narrow and elongated, slightly acute apically. Antenna 13-segmented, if bent backward almost reaching base of $2^{\text {nd }}$ abdominal segment.

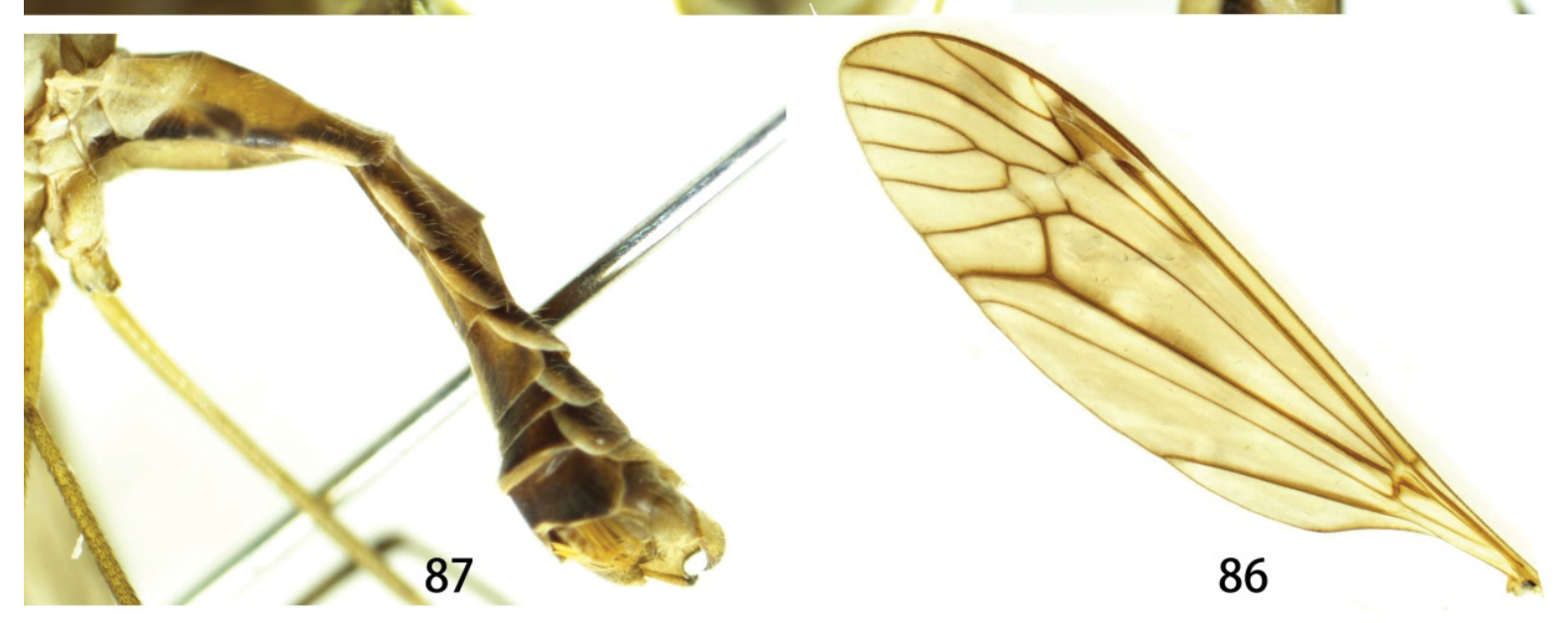

Figs 83-87. Tipula (Vestiplex) reposita Walker, 1848, male. 83 - head, dorsal view; 84 - thorax, dorsal view; 85 - thorax, lateral view; 86 - wing; 87 abdomen and hypopygium, lateral view. 

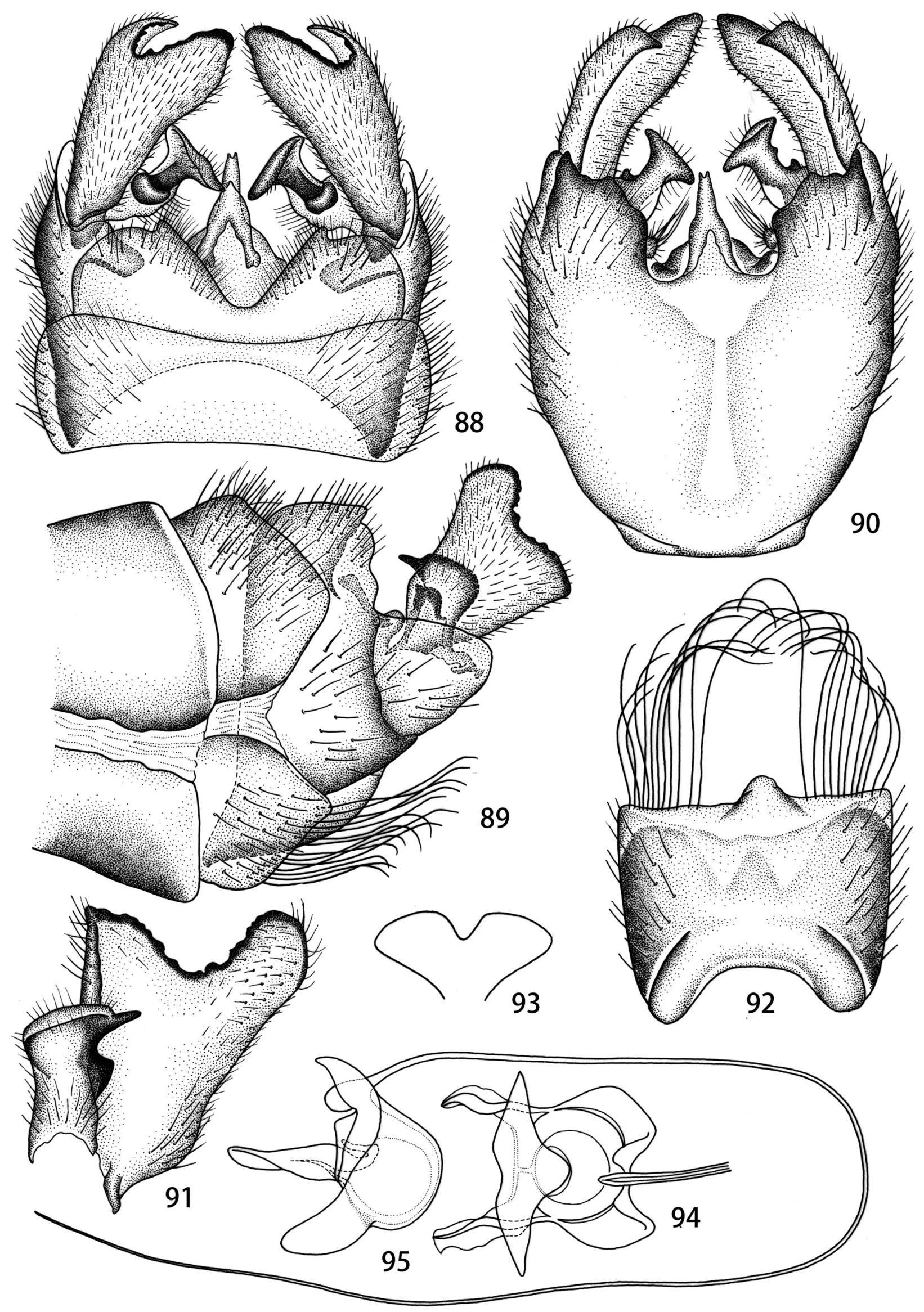

Figs 88-95. Tipula (Vestiplex) reposita Walker, 1848, male. 88 - hypopygium, dorsal view; 89 - hypopygium, lateral view; 90 - hypopygium, ventral view; 91 - right outer and inner gonostyli, lateral view; 92 - sternite eight, ventral view; 93 - compressor apodeme, dorsal view; 94 - semen pump, dorsal view; 95 - semen pump, lateral view. 


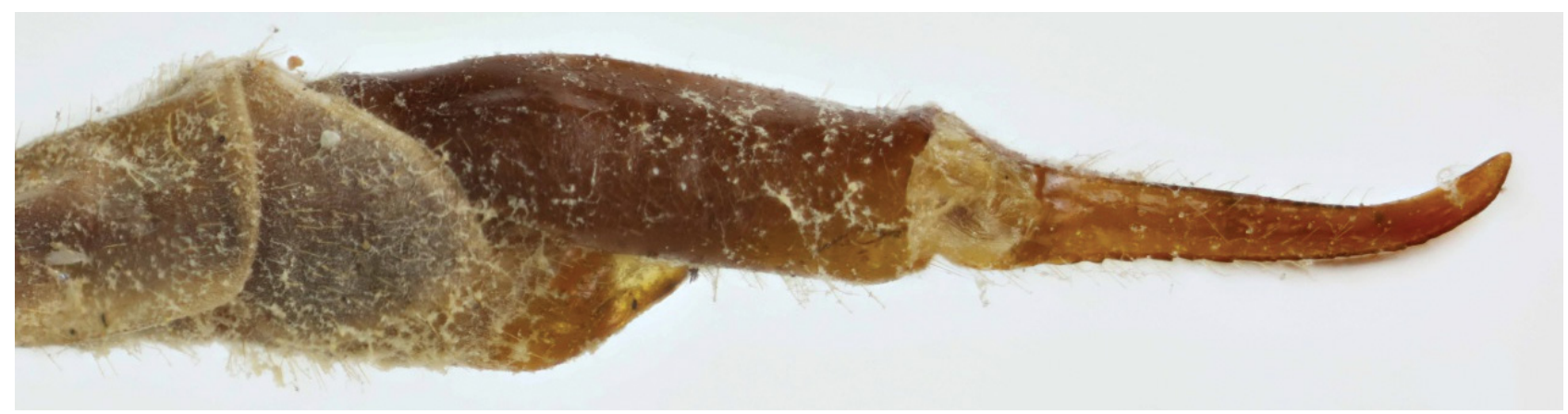

Fig 96. Female terminalia of Tipula (Vestiplex) reposita Walker, 1848, syntype, lateral view.

Scape, pedicel and first flagellomere yellow, all other flagellomeres yellowish brown with base darkened. Apical flagellomere ball-shaped. Flagellomeres except for first enlarged at base, with longest verticils slightly longer than corresponding flagellomeres. Whole flagellum densely covered with short and light setae. Palpus with basal three segments brown, slightly expanded apically, last segment darker in coloration, distinctly longer than basal three segments together.

Thorax. Pronotum yellowish-brown with some dark regions medially and laterally. Prescutum and presutural scutum yellowish-brown with four light brown stripes distinctly bordered by darker brown (Fig. 84). Median stripes separated in middle. Interspace between median and lateral stripes yellowish-brown, with light and short setae. Postsutural scutum yellowish-brown, each lobe with two brown triangular markings connecting to each other, between lobes with narrow brown vitta (Fig. 84). Scutellum yellowish-brown with dark median vitta (Fig. 84). Postnotum yellow with dark vitta. Pleuron entirely yellow (Fig. 85). Legs with coxae and trochanters yellowish-brown, femora yellowish-brown with tip black, tibiae yellowish-brown with tip black, tarsi entirely black. Halter with stem yellow, knob black. Wing brown, with stigma dark brown, base of stigma with round bright spot; bright band extending backward, crossing apical aera of cell $r_{1}$, bases of cells $r_{3}, r_{4}, r_{5}$ and basal area of discal cell; other bright areas including base and apical areas of bm (Fig. 86). Venation: $\mathrm{R}_{1}$ entire, $\mathrm{R}_{2+3+4}$ slightly longer than $\mathrm{R}_{3}, \mathrm{R}_{4}$ of same length as $\mathrm{Rs}, \mathrm{R}_{5}$ curved in apical half, $\mathrm{r}-\mathrm{m}$ two times longer than base of $\mathrm{R}_{5}$, discal cell narrow, more than two times longer than petiole of cell $\mathrm{m}_{1}$, cell $\mathrm{m}_{1}$ more than 3.9 times longer than its petiole (Fig. 86).

Abdomen yellow with dark-brown lateral and median stripes. Median stripe interrupted on tergite three, getting broad toward tergite eight, lateral stripe broad (Fig. 87).

Hypopygium. Male hypopygium yellow. Hypopygium with tergite nine and sternite nine separated at apex, divided at midline by pale region (Figs 88,89 ). Tergite nine rounded laterally, posterior border with deep V-shaped incision, sides of incision relatively straight, densely covered with setae, ends of incision terminating into small rounded lobes (Fig. 88). Gonocoxite small, triangular, apex with darkened short lobe, margin darkened towards mesal region (Fig. 89). Outer gonostylus in shape of large, yellow, flattened plate
(Figs 88-91). Dorsal border serrated, marginally suffused with black, remarkably bifurcated by deep U-shaped notch. Inner gonostylus distinctly smaller than outer gonostylus, upper beak slender, lower beak obtuse, both beaks blackened, dorsal crest with margin nearly rectangular (Figs 88-91). Sternite nine broad, densely covered with setae on lateral surface, posterior border concave, appendage of sternite nine with ventral lobe rounded, densely equipped with long and thin setae (Fig. 90). Adminiculum broad basally with margin raised, narrowed to apex (Fig. 90). Sternite eight concave caudally, anterior border truncated with cone-shaped process medially, with row of very long setae along anterior border, longer than sternite eight (Fig. 92). Semen pump with compressor apodeme fan-shaped, medially with small V-shaped notch, slightly longer than posterior immovable apodeme (Fig. 93). Posterior immovable apodeme with paired arms slightly curved dorsally, broad, terminating into obtuse apex in lateral view (Figs 94, 95). Anterior immovable apodeme broad, flattened in dorsal view (Fig. 95). Aedeagus thick at base, gradually narrowed to apex, more than 7.5 times longer than semen pump (Fig. 95).

Female. Generally similar to male in body coloration.

Female terminalia. Tergites nine and ten shining brown. Cercus brown, with tip narrowed and curved dorsally, ventral margin with rough serration, serration on dorsal margin indistinct (Fig. 96). Hypovalva short, strongly reduced, terminating in two narrowed pale plates, acute apically.

Distribution. China: Chongqing (Alexander 1936, ZHANG et al. 2020), Yunnan (new record), India: Meghalaya (BrunetTi 1918), Laos (ZhANG et al. 2020), Nepal (WALKer 1848), Thailand: Chiang Mai (StARKeVICH et al. 2015), Vietnam (EDWARds 1926).

Remark. The species is easily recognized by remarkable, large bifurcated outer gonostylus, whose unusual shape was highlighted by AlEXANDER (1936).

According to ZHANG et al. (2020), the placement of Tipula reposita in the subgenus Vestiplex is incorrect because of the unique male genital complex. However, the relationship with other Vestiplex species was previously discussed in PiLipenko et al. (2019) based on the male genitalia. The typical female terminalia with powerfully constructed and serrated cerci (Fig. 96) support the assignment of T. reposita as a member of the subgens Vestiplex. 


\section{Checklist of the subgenus Tipula (Vestiplex) from Yunnan and Tibet, China}

T. (V.) adungensis Alexander, 1963 (China: Tibet)

T. (V.) alyxis Alexander, 1963 (China: Tibet, Yunnan)

T. (V.) auriculatalobata Starkevich, Men \& Saldaitis, 2019 (China: Yunnan)

T. (V.) avicularia Edwards, 1928 (China: Tibet, Yunnan; India)

T. (V.) butvilai Starkevich, Saldaitis \& Men, 2019 (China: Yunnan)

T. (V.) distifurca Alexander, 1942 (China: Tibet; India; Myanmar; Nepal; Pakistan)

T. (V.) eurydice Alexander, 1961 (China: Tibet; India)

T. (V.) grahami Alexander, 1933 (China: Sichuan-Tibet border)

T. (V.) guibifida Yang \& Yang, 1992 (China: Tibet, Sichuan, Yunnan, Guizhou)

T. (V.) himalayensis Brunetti, 1911 (China: Sichuan, Yunnan, Tibet; India; Myanmar; Vietnam)

T. (V.) lushuiensis Men \& Starkevich sp. nov. (China: Yunnan)

T. (V.) nigroapicalis Brunetti, 1911 (China: Tibet; India; Nepal)

T. (V.) opilionimorpha Savchenko, 1955 (China: Tibet, Qinghai)

T. (V.) quasimarmoratipennis Brunetti, 1912 (China: Yunnan; India; Indonesia)

T. (V.) reposita Walker, 1848 (China: Yunnan, Sichuan; India; Laos; Nepal; Thailand)

T. (V.) rongtoensis Alexander, 1963 (China: Tibet)

T. (V.) scandens Edwards, 1928 (China: Tibet)

T. (V.) subscripta Edwards, 1928 (China: Tibet, Yunnan)

T. (V.) tardigrada Edwards, 1928 (China: Yunnan)

T. (V.) yunnanensis Alexander, 1942 (China: Yunnan)

T. (V.) zayulensis Alexander, 1963 (China: Tibet)

\section{Key to species of the subgenus Tipula (Vesti- plex) from Yunnan and Tibet, China}

1 Sternite nine ventrally equipped with a pair of nail-like processes. T. (V.) lushuiensis sp. nov.

- Sternite nine without such processes. ....................... 2

2 Tergite nine distally forming a saucer-shaped plate.

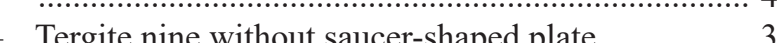

3 Dorsal portion of tergite nine with lobes on posterior margin.

- Dorsal portion of tergite nine without lobes on posterior margin.

4 Gonocoxite horn-shaped.

T. (V.) subscripta Edwards, 1928

- Gonocoxite triangular. ... 6

5 Inner gonostylus with lower beak. .......................... 8

- Inner gonostylus without lower beak.

... T. (V.) butvilai Starkevich, Saldaitis \& Men, 2019

6 Inner gonostylus curved in claw shape, without lower beak. ....................... T. (V.) scandens Edwards, 1928

- Inner gonostylus curved in claw shape, with lower beak. ........ T. (V.) opilionimorpha Savchenko, 1955
7 Abdomen orange, tergites one and seven to nine dark grey, two to six with broad and conspicuous black lateral and median stripes.

T. (V.) tardigrada Edwards, 1928

- Abdomen not as above. ........................................ 11

8 Appendage of sternite nine with dorsal lobe. .......... 9

- Appendage of sternite nine without dorsal lobe. ........

T. (V.) reposita Walker, 1848

9 Gonocoxite produced into two spines or blades. ... 10

- Gonocoxite produced into one blade.

T. (V.) eurydice Alexander, 1961

10 Dorsal lobe of appendage of sternite nine bifurcate. ..

T. (V.) distifurca Alexander, 1942

- Dorsal lobe of appendage of sternite nine not bifurcate. ...... T. (V.) quasimarmoratipennis Brunetti, 1912

11 Tergite nine with anterior margin concave medially, ventral portion terminating into two small dark lobes.

- Tergite nine not as above. ................................... 14

12 Adminiculum laterally with black rods. ............... 13

- Adminiculum without such rods.

T. (V.) himalayensis Brunetti, 1911

13 Antenna with flagellar segments black; outer gonostylus bidentate at tip.

T. (V.) nigroapicalis Brunetti, 1911

- Antenna with flagellar segments bicolored; outer gonostylus with tip round, not bidentate.

T. (V.) alyxis Alexander, 1963

14. Gonocoxite bifurcated, upper lobe rounded, lower lobe narrowed and curved dorsally. ....................... 15

- Gonocoxite not as above. ........................................ 16

15 Thorax greenish grey, antenna with flagellum dark brown. .................. T. (V) avicularia Edwards, 1928

- Thorax yellow, antenna with flagellum bicolored. ..... T. (V.) guibifida Yang \& Yang, 1992

16 Ventral portion of tergite nine with a pair of slender black lobes that weakly capitate or dilate at apex, margin serrulate or roughened. ................................. 17

- Ventral portion of tergite nine without such lobe. ... 18

17 Mesonotal prescutum grey with four olive-grey stripes. ...................... T. (V.) grahami Alexander, 1933

- Mesonotal prescutum brown or yellowish-brown with four brown stripes.

T. (V.) yunnanensis Alexander, 1942

18 Ventral portion of tergite nine with a pair of broadened, ear-shaped lobes. ......... T. (V.) auriculatalobata

Starkevich, Men \& Saldaitis, 2019

- Ventral portion of tergite nine without such lobes. ... 19

19 Femur with subterminal yellow ring.

T. (V.) zayulensis Alexander, 1963

- Femur without subterminal ring. ........................... 20

20 Femur with narrowly blackened tip.

T. (V.) rongtoensis Alexander, 1963

- Femure with broadly blackened tip.

T. (V.) adungensis Alexander, 1963

\section{Acknowledgements}

The authors wish to express sincere thanks to Dr. P. Oosterbroek (Naturalis Biodiversity Center, Leiden, 
the Netherlands) for his valuable website, the Catalogue of the Crane flies of the World, from which we obtained a lot of valuable information. We are also grateful to the staff of Administrative Bureau of Cibagou National Nature Reserve. We also sincerely thank Dr. P. Oosterbroek and Dr. J. Starý (Olomouc-Nedvězí \& Silesian Museum, Opava, Czech Republic) who provided valuable comments and advices on the manuscript. We are grateful to the following museum curators for their help and assistance in obtaining specimens: Dr. D. Sivell, BMNH, United Kingdom; Dr. T. Dikow, USNM, USA; Dr. J. Gelhaus, ANSP, USA.

We do also express our thanks to A. Saldaitis, Dr. S. Podenas, NRC, Lithuania, and Dr. D. Kato, BLKU, Japan for their kindness while sharing photos of C. P. Alexander's slides and providing additional specimens of $T$. (Vestiplex) used in this paper. This study was supported by the National Natural Science Foundation of China (31300551), the Anhui Outstanding Young Talent Support Program (gxbjZD2020073), the Foundation of the Education Department of Anhui Province (KJ2017A360), and the Natural Science Foundation of Anhui Province, China (1808085MC59). The visit of P. Starkevich to the BMNH (Revisionary Systematics and Phylogenetic Analysis of the Crane Fly Subgenus Tipula (Vestiplex) (GB-TAF-5424)) was supported by the SYNTHESYS Project http://www. synthesys.info/ which was financed by the European Community Research Action under the FP7 Integrating Activities Programme.

\section{References}

ALEXANDER C. P. 1935a: New or little-known Tipulidae from eastern Asia (Diptera). XXV. Philippine Journal of Science 57: 81-148.

ALEXANDER_C. P. 1935b: New or little-known Tipulidae from eastern Asia (Diptera). XXIV. Philippine Journal of Science 56: 525-562.

ALEXANDER C. P. 1963a: Classification and synonymy of the crane-flies described by Enrico Brunetti (Diptera: Families Ptychopteridae, Trichoceridae and Tipulidae). Records of the Indian Museum 59: 19-34.

ALEXANDER C. P. 1963b: Some Tipulidae from Tibet and upper Burma in the British museum (natural history) (Diptera). Bulletin of the British Museum (Natural History), Entomology 14: 319-340.

ALEXANDER C. P. 1933: New or little-known Tipulidae from eastern Asia (Diptera). XIV. Philippine Journal of Science 51: 507-544.

ALEXANDER C. P. 1936: New or little-known Tipulidae from eastern Asia (Diptera). XXIX. Philippine Journal of Science 59: 225-257.

ALEXANDER C. P. 1942: The Oriental Tipulidae in the collection of the Indian museum. Part II. Records of the Indian Museum 44: 29-72.

AlLEXANDER C. P. 1953: The Oriental Tipulidae in the collection of the Indian museum. Part III. Records of the Indian Museum 50: 321-357.

ALEXANDER C. P. 1965: Family Tipulidae. Pp. 16-90. In: STONE A., SABROSKY C. W., WIRTH W. W., FOOTE R. H. \& COULSON J. R. (eds.): A catalog of the Diptera of America north of Mexico. United States Department of Agriculture, Agriculture Handbook, $1696 \mathrm{pp}$.

ALEXANDER C. P. \& ALEXANDER M. M. 1973: Family Tipulidae. Pp. 10-224. In: DELFINADO M. D. \& HARDY D. E. (eds.): A Catalog of the Diptera of the Oriental Region, Volume 1. The University Press of Hawaii, Honolulu, 618 pp.

ALEXANDER C. P. \& BYERS G. W. 1981: Tipulidae. Pp. 153-190. In: McALPINE J. F., PETERSON B. V., SHEWELL G. E., TESKEY H. J., VOCKEROTH J. R. \& WOOD D. M. (eds.): Manual of Nearctic Diptera. Vol. 1. Biosystematics Research Institute, Ottawa, Ontario, 647 pp.

BEZZI M. 1924: Una nuova Tipula delle Alpi con ali ridotte anche nel maschio (Dipt.). Annali del Museo Civico di Storia Naturale di Genova 51: 228-233.
BRUNETTI E. 1911: Revision of the Oriental Tipulidae with descriptions of new species. Records of the Indian Museum 6: 231-314.

BRUNETTI E. 1912: Diptera Nematocera (excluding Chironomidae and Culicidae). Fauna of British India, including Ceylon and Burma 1: $1-581$.

BRUNETTI E. 1918: Revision of the Oriental Tipulidae with descriptions of new species, Part 2. Records of the Indian Museum 15: 255-344.

CUMMING J. M. \& WOOD D. M. 2017: Adult morphology and terminology. Pp. 89-133. In: KIRK-SPRIGGS A. H. \& SINCLAIR B. J. (eds.): Manual of Afrotropical Diptera, Volume 1: Introductory Chapters and Keys to Diptera Families. Suricata 4. South African National Biodiversity Institute, Pretoria, $425 \mathrm{pp}$.

DUTTA M., PARUI P. \& MUKHERJEE M. 1997: Insecta: Diptera. State Fauna Series 3, Fauna of West Bengal 7: 1-76.

EDWARDS F. W. 1924: Notes on the types of Diptera Nematocera (Mycetophilidae and Tipulidae), described by Mr. E. Brunetti. Records of the Indian Museum 26: 291-307.

EDWARDS F. W. 1926: On some crane-flies from French Indo-China. Encyclopedie Entomologique, (B II), Diptera 3: 48-55.

EDWARDS F. W. 1931: Some suggestions on the classification of the genus Tipula (Diptera, Tipulidae). Annals and Magazine of Natural History, Series 10 8: 73-82.

GELHAUS J. K. 2005: Systematics and biogeography of the desert crane fly subgenus Tipula (Eremotipula) Alexander (Diptera: Tipulidae). Memoirs of the American Entomological Society 46: 1-235.

JONG H. DE 2017: Limoniidae and Tipulidae. Pp. 427-477. In: KIRK-SPRIGGS A. H. \& SINCLAIR B. J. (eds.): Manual of Afrotropical Diptera. Volume 2. Nematocerous Diptera and lower Brachycera. Suricata 5. South African Biodiversity Institute, Pretoria, 920 pp.

JOSEPH A. N. T. 1974: The Brunetti types of Tipulidae (Diptera) in the collection of the Zoological Survey of India. Part III. Tipula Linnaeus. Oriental Insects 8: 241-280.

MANNHEIMS B. 1953: 15. Tipulidae. In: LINDNER E. (ed.): Die Fliegen der palaearktischen Region, 3(5)1, Lief. 238: 137-176.

MEN Q. L., YOUNG C. W., STARKEVICH P., YU Y. F. \& LEI X. P. 2017: Two new species of Tipula (Vestiplex) from Southern China based on morphological and molecular data, with redescription of Tipula (Vestiplex) bicalcarata (Diptera, Tipulidae, Tipulinae). ZooKeys 658: 63-80.

MITRA B. \& BHATTACHARYA K. 2010: Insecta: Diptera. State Fauna Series 18, Fauna of Uttarakhand 2: 361-411.

OOSTERBROEK P. 2021: Catalogue of the Craneflies of the World (Diptera, Tipuloidea: Pediciidae, Limoniidae, Cylindrotomidae, Tipulidae). https://ccw.naturalis.nl/index.php (Last update: 11 Apr. 2021)

OOSTERBROEK P. \& THEOWALD BR. 1992: Family Tipulidae. Pp. 56-178. In: SOÓS Á., PAPP L. \& OOSTERBROEK P. (eds.): Catalogue of Palaearctic Diptera 1. Hungarian Natural History Museum, Budapest, $520 \mathrm{pp}$.

PILIPENKO V. E., STARKEVICH P. \& GAVRYUSHIN D. I. 2019: A new Tipula (Vestiplex) Bezzi crane fly species (Diptera, Tipulidae) from Vietnam. Entomologica Americana 125: 10-15.

SAVCHENKO E. N. 1960: Scientific results of the Chinese-Soviet zoological-botanical expeditions of 1955-1957 to South-Western China. On the crane-flies (Diptera, Tipulidae) of SW China. Entomologicheskoe Obozrenie 39: 885-892 (in Russian with English summary).

SAVCHENKO E. N. 1964: Crane-flies (Diptera, Tipulidae), Subfam. Tipulinae, Genus Tipula L., 2. Fauna USSR, N.S. 89, Insecta Diptera. Vol. 2(4). Nauka, Moscow, Leningrad, 503 pp (in Russian).

STARKEVICH P., SALDAITIS A. \& MEN Q. L. 2019: Tipula (Vestiplex) butvilai sp. nov., a new crane fly (Diptera, Tipulidae) from Yunnan, China. ZooKeys 869: 91-101.

STARKEVICH P. \& PODENAS S. 2011: New faunistic records of Tipula (Vestiplex) crane flies (Diptera: Tipulidae) for China and Myanmar. Acta Zoologica Lituanica 21: 273-278.

STARKEVICH P., PODENAS S. \& YOUNG C. W. 2015: New distribution records for crane flies of Tipula (Vestiplex) Bezzi (Diptera, Tipulidae). Journal of the Kansas Entomological Society 88: 121-123.

WALKER F. 1848: List of specimens of dipterous insects in the collection of the British Museum. Volume 1. British Museum, London, 229 pp. 
YANG D. \& YANG C. K. 1992: Diptera: Tipulidae. Pp. 576-579. In: HUANG F. S. (ed.): Insects of Wuling Mountains Area, Southwestren China. Science Press, Beijing, China, 776 pp.

YANG D., GAO C. X. \& YOUNG C. W. 2006: Tipulidae. Pp. 445-449. In: LI Z. Z \& JIN D. C. (eds.): Insects from Fanjingshan landscape. Insect Fauna from National Nature Reserve in Guizhou Province.
Vol. 4. Guizhou Science and Technology Press, Guiyang, China, 780 pp (in Chinese with English summary).

ZHANG B., REN J. L., LI Y. \& YANG D. 2020: New and little-known species of Tipula Linnaeus (Diptera, Tipulidae) from Laos, with a new synonym. ZooKeys 982: 11-31. 